\title{
Effect of CO2-induced ocean acidification on the early development and shell mineralization of the European abalone (Haliotis tuberculata)
}

\author{
Wessel Nathalie 1, 2, Martin Sophie ${ }^{3,8}$, Badou Aicha ${ }^{1}$, Dubois Philippe ${ }^{4}$, Huchette Sylvain ${ }^{5}$, \\ Julia Vivien ${ }^{1,6}$, Nunes Flavia ${ }^{6,7}$, Harney Ewan ${ }^{6}$, Paillard Christine ${ }^{6}$, Auzoux-Bordenave Stéphanie ${ }^{1,8,{ }^{*}}$
}

${ }^{1}$ MNHN CNRS IRD UPMC, Stn Biol Marine Concarneau, Museum Natl Hist Nat, UMR 7208,Biol

Organismes \& Ecosyst Aquat BOREA, F-29900 Concarneau, France.

2 IFREMER, Dept Oceanog \& Dynam Ecosyst ODE, Rue lile Yeu,BP21105, F-44311 Nantes 3, France.

${ }^{3}$ Stn Biol Roscoff, AD2M, UMR 7144, F-29680 Roscoff, France.

${ }^{4}$ Univ Libre Bruxelles, Lab Biol Marine, CP160-15, B-1050 Brussels, Belgium.

${ }^{5}$ Ecloserie France Haliotis, F-29880 Kerazan, Plouguerneau, France.

6 UEB, Univ Brest UBO, Lab Sci Environm Marin LEMAR, UMR 6539 CNRS UBO IRD Ifremer,Inst Univ Europeen, PI Nicolas Copernic, F-29280 Plouzane, France.

7 IFREMER, Ctr Bretagne, DYNECO, Lab Coastal Benth Ecol LEBCO, F-29280 Plouzane, France.

8 Sorbonne Univ, 4 PI Jussieu, F-75005 Paris, France.

* Corresponding author : Stéphanie Auzoux-Bordenave, email address :

stephanie.auzoux-bordenave@mnhn.fr

\begin{abstract}
:
Ocean acidification is a major global stressor that leads to substantial changes in seawater carbonate chemistry, with potentially significant consequences for calcifying organisms. Marine shelled mollusks are ecologically and economically important species providing essential ecosystem services and food sources for other species. Because they use calcium carbonate $(\mathrm{CaCO})$ to produce their shells, mollusks are among the most vulnerable invertebrates to ocean acidification, with early developmental stages being particularly sensitive to $\mathrm{pH}$ changes. This study investigated the effects of $\mathrm{CO} 2$-induced ocean acidification on larval development of the European abalone Haliotis tuberculata, a commercially important gastropod species. Abalone larvae were exposed to a range of reduced $\mathrm{pHs}(8.0,7.7$ and 7.6) over the course of their development cycle, from early-hatched trochophore to pre-metamorphic veliger. Biological responses were evaluated by measuring the survival rate, morphology and development, growth rate and shell calcification. Larval survival was significantly lower in acidified conditions than in control conditions. Similarly, larval size was consistently smaller under low pH conditions. Larval development was also affected, with evidence of a developmental delay and an increase in the proportion of malformed or unshelled larvae. In shelled larvae, the intensity of birefringence decreased under low $\mathrm{pH}$ conditions, suggesting a reduction in shell mineralization. Since these biological effects were observed for $\mathrm{pH}$ values expected by 2100 , ocean acidification may have potentially negative consequences for larval recruitment and persistence of abalone populations in the near future.
\end{abstract}




\section{Highlights}

- Calcifying mollusks are among the most vulnerable invertebrates to $(\mathrm{OA})$. are particularly sensitive to $\mathrm{pH}$ changes. We investigated the effects of $\mathrm{OA}$ on larval development of the abalone $H$. tuberculata, a commercially important gastropod. Larval survival, development and shell calcification were affected by low pH conditions. OA may have potentially negative consequences for larval recruitment and persistence of abalone populations.

Keywords : Ocean acidification, Abalone, Larval development, Shell mineralization 
51 Ocean acidification and warming are major concerns for marine ecosystems. By the

52 end of the $21^{\text {st }}$ century, global mean surface temperatures are expected to increase by 1

53 to $3^{\circ} \mathrm{C}$, while surface ocean $\mathrm{pH}$ is likely to decrease by 0.1 to 0.3 units (Gattuso et al.,

54 2015). These changes will lead to alterations in seawater carbonate chemistry and a

55 reduction in the degree of saturation with respect to calcium carbonate (Gattuso et al.,

56 2015; IPCC, 2014). Since marine benthic ecosystems constitute a reservoir for

57 biodiversity, several studies have focused on the evaluation of changing ocean

58 conditions on marine biodiversity via the measurement of key physiological and

59 ecological processes in marine organisms (for a review, see Widdicombe and Spicer, 60 2008).

61 Changing ocean conditions are considered as major threats to marine species, 
affecting early development, skeletal growth and key physiological functions, which can ultimately impact animal behaviour and species distribution (Kroeker et al., 2010; Widdicombe and Spicer, 2008). Reduced oceanic $\mathrm{pH}$ has been shown to impact a variety of calcifying species, such as corals, mollusks and echinoderms, leading to contrasting biological responses (Hendricks et al., 2010; Hofmann et al., 2010; Wittmann and Pörtner, 2013). Because calcium carbonate $\left(\mathrm{CaCO}_{3}\right)$ is necessary for shell production, mollusks are among the most vulnerable invertebrates to ocean acidification, with larval and juvenile stages being particularly vulnerable (Gazeau et al., 2013; Orr et al., 2005; Przeslawski et al., 2015 Talmage and Gobler, 2010). Indeed, it is during larval development that marine mollusks initiate the deposition of calcium carbonate $\left(\mathrm{CaCO}_{3}\right)$ to build their shell (Kurihara, 2008).

A number of studies have reported delays in development, reduced growth rate and/or shell abnormalities in larval mollusks that could potentially affect larval survival, metamorphosis and recruitment into adult populations (Parker et al., 2013; Ross et al., 2011). The impacts of ocean acidification may be particularly severe for bivalves and gastropods, which start to calcify at early developmental stages (Parker et al., 2013). Since many mollusk species are commercially important food sources, negative impacts of ocean acidification may also result in significant economic loss (Ekstrom et al., 2015; Gazeau et al., 2007). Several studies have recently focused on the impacts of elevated partial pressure of $\mathrm{CO}_{2}\left(p \mathrm{CO}_{2}\right)$ on embryonic and larval stages of shelled mollusks, especially cultivated bivalves (see reviews by Gazeau et al., 2013; Parker et al., 2013). In comparison to marine bivalves, our knowledge of the impacts of elevated $p \mathrm{CO}_{2}$ on early developmental stages in gastropods is based on fewer studies, covering only about four genera (Cavolinia, Crepidula, Littorina and Haliotis). In the gastropods studied to date, ocean acidification was shown to reduce larval survival, increase development time, alter morphology and/or impair shell formation and calcification (Byrne et al., 
2011; Comeau et al., 2010; Crim et al., 2011; Ellis et al., 2009; Guo et al., 2015; Kimura et al., 2011; Noisette et al., 2014; Zippay and Hofmann, 2010).

Among the species that have been considered in acidification studies, abalone (Haliotis spp.) are ecologically and economically important, acting as grazers in the marine ecosystem and as a food source for humans (Cook, 2014; Huchette and Clavier, 2004). Many abalone species worldwide have experienced severe population declines due to both overfishing and the combined effects of environmental stressors such as elevated $\mathrm{CO}_{2}$, global warming and pathogen occurrence (Crim et al., 2011; Travers et al., 2009; Morash and Alter, 2015). Early-life-history stages of abalone appear to be negatively affected by elevated $\mathrm{CO}_{2}$, with a higher percentage of deformed larvae under low $\mathrm{pH}$ conditions than other intertidal marine mollusks such as oysters (Byrne et al., 2011; Crim et al., 2011; Guo et al., 2015; Kimura et al., 2011; Zippay and Hofmann, 2010). For example, elevated seawater $\mathrm{CO}_{2}$ concentrations impaired larval development and reduced larval survival in the northern abalone Haliotis kamtschatkana (Crim et al., 2011). In the abalone $H$. coccoradiata, embryos were dramatically affected by a combination of warm $\left(+2\right.$ to $\left.+4^{\circ} \mathrm{C}\right)$ and acidified conditions $(-0.4$ to $-0.6 \mathrm{pH}$ units $)$ with only a small percentage surviving, and with those embryos that did survive producing unshelled larvae (Byrne et al., 2011).

The European abalone Haliotis tuberculata is a commercially important mollusk species, for which the whole life cycle is completed under anthropogenic control

108 (Courtois de Viçose et al., 2007). As for most marine invertebrates, abalone display a 109 pelago-benthic life cycle with a larval planktonic stage followed by a critical 110 metamorphosis into the benthic juvenile, making them highly sensitive to environmental 111 changes (Byrne et al., 2011). Larval development and shell formation have been 112 extensively studied in $H$. tuberculata, with deposition of amorphous calcium carbonate 113 (ACC) in the early larval shell followed by deposition of aragonite in the juvenile and 
114 adult shell (Auzoux-Bordenave et al., 2010). Since ACC and aragonite are relatively

115 soluble forms of $\mathrm{CaCO}_{3}$ (compared to calcite), the abalone shell is a relevant model for

116 investigating the effects of ocean acidification. The controlled production of Haliotis

117 tuberculata embryos and larvae provides a unique opportunity to study the impact of

118 acidification on the early development of a marine calcifying species.

119 Here we investigated the effects of $\mathrm{CO}_{2}$-induced ocean acidification on survival,

120 early development, growth and shell mineralization during the entire larval development

121 of the European abalone Haliotis tuberculata. Abalone larvae, obtained from a

122 controlled fertilization carried out at the 'France-Haliotis' hatchery, were exposed to

123 three experimental pHs (8.0, 7.7 and 7.6) throughout their larval development.

124 Biological responses of larvae were evaluated by measuring the survival rate,

125 morphology and development, growth and shell calcification. Optical and SEM

126 microscopy analyses were performed to assess whether reduced $\mathrm{pH}$ had an influence on

127 larval shell morphology and microstructure.

128

\section{Materials and methods}

130

\subsection{Production of abalone larvae}

Haliotis tuberculata parental stock were collected from northwest Brittany (Roscoff,

133 France) and conditioned in flowing seawater at the 'France-Haliotis' commercial

134 abalone hatchery (Plouguerneau, France). Larvae were obtained from controlled

135 fertilizations carried out in September 2013 at a water temperature of $17.0 \pm 0.5^{\circ} \mathrm{C}$,

136 which led to approximately $6 \times 10^{6}$ larvae. Following fertilization, egg density was

137 evaluated under a binocular microscope and the embryos were transferred to

138 experimental tanks for acidification experiments. 
140 The effects of lowered $\mathrm{pH}$ were investigated by exposing abalone larvae to three $\mathrm{pH}$

141 conditions, including one present-day control pH $8.0\left(\mathrm{CO}_{2} \approx 400 \mu \mathrm{atm}\right)$ and two levels

142 of $\mathrm{pH}$ predicted under varying climate change scenarios: $7.7\left(p \mathrm{CO}_{2} \approx 1000 \mu \mathrm{atm}\right)$ and

$1437.6\left(p \mathrm{CO}_{2} \approx 1400 \mu \mathrm{atm}\right)$, as outlined by Riebesell et al. (2010). Experiments were carried

144 out in September 2013 at the 'France-Haliotis' hatchery, according to an experimental

145 design adapted from Martin et al. (2011). Fertilized embryos were grown in $300 \mathrm{~L}$ tanks

146 of flowing seawater at a density of $5 \times 10^{5}$ per tank, under the three $p \mathrm{CO}_{2}$ conditions, and

147 with two replicate tanks per condition. The effects of seawater acidification were

148 investigated over the total duration of larval development (5 days), from early-hatched

149 trochophore larvae to the pre-metamorphic stage. Haliotis larvae are lecithotrophic and

150 were not fed during the experiment, avoiding any influence of diet on the biological

151 responses.

\subsection{1. $\mathrm{pH}$ control and carbonate chemistry}

154 Larval tanks were kept in a temperature-controlled room and supplied with natural

155 filtered seawater that was continuously aerated with ambient air. The temperature and

156 salinity were measured daily using a conductimeter (3110, WTW, Germany). Low

157 seawater $\mathrm{pH}$ was obtained by bubbling $\mathrm{CO}_{2}$ (Air liquide, France) into the tanks through

158 electro-valves regulated by a $\mathrm{pH}$-stat system (Aquastar, IKS Computer System,

159 Germany). Seawater $\mathrm{pH}\left(\mathrm{pH}_{\mathrm{T}}\right.$, expressed on the total hydrogen ion concentration scale,

160 Dickson, 2010) was adjusted to the desired level from ambient $\mathrm{pH}_{\mathrm{T}}(8.0)$ to low $\mathrm{pH}_{\mathrm{T}}$

161 (7.7 and 7.6) to within $\pm 0.05 \mathrm{pH}$ units. $\mathrm{pH}$ values on the National Bureau of Standards

162 (NBS) scale obtained with the $\mathrm{pH}$-stat system were adjusted daily with measurements of $163 \mathrm{pH}_{\mathrm{T}}$ for each tank using a $\mathrm{pH}$ meter (Metrohm $826 \mathrm{pH}$ mobile, Metrohm, Switzerland) 
164 with a glass electrode (Metrohm electrode plus) calibrated on the total scale using

165 Tris/ $\mathrm{HCl}$ and 2-aminopyridine/HCl buffer (Dickson et al., 2007). pH (NBS) was

166 recorded every 15 minutes in each tank by the $\mathrm{pH}$-stat system and converted to $\mathrm{pH}_{\mathrm{T}}$ by

167 using daily measurements.

168 Total alkalinity $\left(\mathrm{A}_{\mathrm{T}}\right)$ of seawater was measured twice on $100 \mathrm{ml}$ samples taken from

169 incoming water and from each experimental tank. Seawater samples were filtered

170 through $0.7 \mu \mathrm{m}$ Whatman $\mathrm{GF} / \mathrm{F}$ membranes, immediately poisoned with mercuric

171 chloride and stored in a cool dark place pending analyses. $\mathrm{A}_{\mathrm{T}}$ was determined

172 potentiometrically using an automatic titrator (Titroline alpha, Schott SI Analytics,

173 Germany) calibrated with the National Bureau of Standards scale. $\mathrm{A}_{\mathrm{T}}$ was calculated

174 using a Gran function applied to $\mathrm{pH}$ values ranging from 3.5 to 3.0 as described by

175 Dickson et al. (2007) and corrected by comparison with standard reference material

176 provided by Andrew G. Dickson (CRM Batch 111). $p \mathrm{CO}_{2}$ and other parameters of

177 carbonate chemistry were determined from $\mathrm{pH}_{\mathrm{T}}, \mathrm{A}_{\mathrm{T}}$, temperature and salinity by using

178 the $\mathrm{CO}_{2} \mathrm{SYS}$ software (Lewis and Wallace, 1998) using constants from Mehrbach et al.

179 (1973) refitted by Dickson and Millerro (1987).

180

\subsubsection{Larval sampling and measurements}

Larval development was monitored by daily observations with a binocular

183 microscope. Larvae were sampled at four different development stages: trochophore

184 (approximately 20 hours post fertilization, hpf), early veliger ( $30 \mathrm{hpf}$ ), post-torsional veliger (48 hpf) and pre-metamorphic stage (96 hpf). At each sampling time point, 10 $12 \mathrm{~L}$ of seawater containing larvae were collected from each tank. Larval viability was

187 calculated at each stage as the proportion of live larvae divided by the total number of 188 larvae $(\mathrm{n} \approx 200)$. Larvae were filtered on a $40 \mu \mathrm{m}$-sieve and aliquoted into $15 \mathrm{ml}$ tubes. 189 Larval samples were then fixed in either $70 \%$ ethanol for transmitted and polarized light 
190 microscopy or in a 3\% glutaraldehyde solution in Sörensen-sucrose buffer, adjusted to

$1911100 \mathrm{mOsm}$ for SEM analysis.

192

\subsection{Light and polarized microscopy}

\subsubsection{Slide preparation and observation}

Microscopic slides were prepared with ethanol-fixed larvae from the different $\mathrm{pH}$ conditions (two slides per condition). Approximately 100 larvae were whole-mounted in

a drop of glycerol, with the amount of ethanol transferred kept to a minimum. Slides were kept at room temperature for 5 to $10 \mathrm{~min}$, allowing ethanol to evaporate and larvae to settle. Four spots of vacuum gel were deposited on the corners of a squared cover slip to prevent the larvae being crushed. After placing the cover slip over the glycerol, the slides were gently sealed with varnish. About 200 larvae per condition were observed and photographed under phase contrast and polarized light with an Olympus binocular microscope (Olympus, Hamburg, Germany) equipped with polarizing filters. All images were acquired with a digital camera (DS-Ri1, Nikon) at 100x magnification and $40 \mathrm{~ms}$ light exposition. Images were analyzed with NIS-element and Image-J software.

\subsubsection{Morphometrical analysis}

Larval development stage, shell presence and size were determined under light

210 length and width of normal larvae were measured in specimens lying on the lateral side,

211 as shown by the dotted black arrows in Figure 1. The product of length * width was

212 calculated for each larva and the mean of these values per tank was computed. A growth 213 index per tank was calculated as the square root of each of these means. 
214 Trochophore larvae were scored as one of four possible morphological groups,

215 according to the presence/absence of larval shell, the occurrence of body abnormalities

216 and/or delayed development:

217 1- normal shelled larvae (Fig 1A),

218 2- shelled larvae with abnormalities or delayed development,

219 3- unshelled larvae with normal body (Fig 1B),

220 4- unshelled larvae with abnormalities or delayed development,

221 For veliger stages, the presence/absence of shell, body abnormalities and/or delayed

222 development were also recorded. Additional attributes like mantle formation,

223 appearance of eyes or tentacles, and shell abnormalities were included for the

224 assessment of morphological status.

225 According to these parameters, veliger larvae were scored as one of the following four 226 morphological groups:

227 1- normal shelled larvae (Fig. 2A, D, G)

228 2- larvae with shell malformation (Fig. 2B, E)

229 3- larvae presenting body abnormalities or delayed development (Fig. 2H)

230 4- larvae with both shell and body abnormalities (Fig. 2C, F, I)

231

232

\subsubsection{Birefringence analysis}

The degree of $\mathrm{CaCO}_{3}$ mineralization within the larval shell was evaluated by

234 measuring the intensity of birefringence under cross-polarized light using an Olympus

235 microscope, according to the method described by Jardillier et al. (2008). Cross-

236 polarized light passing through calcium carbonate (an anisotropic material) is double

237 refracted. As shells with higher calcium carbonate content double refract more light, the

238 intensity of birefringence can be used as a proxy for the evaluation of shell 
239 mineralization (Noisette et al., 2014). Measurements were obtained for 30, 48 and 96

240 hpf larvae. Earlier larval stages were not considered because their shell lacked sufficient

241 crystallized $\mathrm{CaCO}_{3}$ to calculate birefringence. Birefringence was determined for 40

242 larvae per treatment using Image $\mathbf{J}$ software. The mean of grey-scale level (in pixels)

243 was determined for each area of the larval shell showing birefringence (1 to 3 areas per

244 larval shell). The values for each area were averaged into a global mean grey-scale

245 value, providing the birefringence intensity (in \%) for each larval shell (Fig S1,

246 electronic supplementary material). Larvae were categorized as one of three types: fully

247 mineralized (birefringence $>90 \%)$; partially mineralized $(70 \%<$ birefringence $<90 \%)$

248 and less mineralized (birefringence $<70 \%$ ). Finally, the birefringence intensity of larval

249 shells grown under the different $\mathrm{pH}$ conditions was expressed as a percentage of larvae

250 distributed in the three categories for each developmental stage.

\subsection{Scanning electron microscopy (SEM)}

Four individuals per $\mathrm{pH}$ condition were used for SEM analysis. Larval samples were fixed in a 3\% glutaraldehyde solution and then washed in Sörensen-sucrose buffer. Samples were subsequently dehydrated in a series of increasingly concentrated ethanol solutions and were critical point dried with liquid carbon dioxide. Finally, samples were carbon-coated and observed at the "Plateforme d'Imagerie et de Mesures en Microscopie" (PIMM, Université de Bretagne Occidentale, Brest, France) with a scanning electron microscope operating at $5 \mathrm{kV}$ (Hitachi S-3200N). 


\subsection{Statistical analyses}

All statistical analyses were performed with R software (R Development Core Team, 2014) or Systat 12. In order to determine if larval viability was significantly different between $\mathrm{pH}$ treatments, an unpaired Student's t-test with Welch correction was performed. For morphological and developmental data, a homogeneity $\chi^{2}$ test was performed in order to evaluate the effect of elevated $p \mathrm{CO}_{2}$ on larval phenotypes. Correlation between larval length and width across $\mathrm{pH}$ treatments was assessed using a Spearman's correlation test, allowing length and width to be combined as one parameter to estimate growth. Differences in larval growth across $\mathrm{pH}$ treatments were assessed by repeated measures ANOVA using the growth index per tank ( $\mathrm{pH}$ : fixed crossed factor, time: fixed repeated factor) followed by post-hoc Tukey tests for multiple comparisons using the appropriate mean square error (Doncaster and Davey, 2007). To test the effect of $\mathrm{pH}$ on shell birefringence, a homogeneity $\chi^{2}$ test was performed followed by a pairwise Wilcoxon rank sum. For all tests, differences were considered significant at $p<$ 0.05 .

\section{Results}

\subsection{Seawater parameters}

Mean values of seawater carbonate chemistry parameters are reported in Table 1.

280 The $\mathrm{pH}_{\mathrm{T}}$ of experimental aquaria was maintained closed to nominal values throughout

281 the experiment, respectively at a $\mathrm{pH}_{\mathrm{T}}=8.0\left(\mathrm{CO}_{2}\right.$ of $\left.460 \mu \mathrm{atm} \pm 3 \mu \mathrm{atm}\right), \mathrm{pH}_{\mathrm{T}}=7.68$ $\left(p \mathrm{CO}_{2}\right.$ of $\left.1055 \pm 3 \mu \mathrm{atm}\right)$ and $\mathrm{pH}_{\mathrm{T}}=7.58\left(p \mathrm{CO}_{2}\right.$ of $\left.1331 \pm 10 \mu \mathrm{atm}\right)$. In the following sections, rounded mean $\mathrm{pH}_{\mathrm{T}}$ values are used namely $\mathrm{pH}$ 8.0, 7.7, and 7.6). The temperature was maintained at $17.0 \pm 0.5^{\circ} \mathrm{C}(\mathrm{n}=5)$ and salinity at $37.0 \pm 0.1(\mathrm{n}=5)$ in all tanks and there were no significant differences across treatments. Total alkalinity 
$286\left(\mathrm{~A}_{\mathrm{T}}\right)$ measured from incoming water and from experimental tanks differed only slightly

287 and remained stable over the experiment (mean $\left.=2344 \mu \mathrm{Eq} \cdot \mathrm{kg}^{-1}\right)$.

288

289

290

291

292

\subsection{Larval viability}

Larval viability was measured for the three development stages in the different $\mathrm{pH}$ conditions (Fig. 3). In control seawater ( $\mathrm{pH} 8.0$ ) larval viability remained $>95 \%$ until the pre-metamorphic stage. A significant decrease in larval viability was observed in reduced $\mathrm{pH}$ treatments. At $\mathrm{pH} 7.7$ reduced larval viability was observed in 30 and 48 hpf larvae, although the decrease was not significant $(p=0.257$ and $p=0.125$ respectively), but a 50\% reduction in viability at 96 hpf was significant (unpaired Student's t-test, $p<0.001)$. At $\mathrm{pH} 7.6$, viability slightly decreased to $75 \%$ at $30 \mathrm{hpf}(p=$ 0.067 ) and dropped to $56 \%$ and $47 \%$ at 48 and 96 hpf respectively (unpaired Student's ttest, $p=0.001$ and $p=0.008$ respectively). Abnormalities in larval morphology and hyperactive movements were observed in the two low $\mathrm{pH}$ conditions for all four larval stages (S. Auzoux-Bordenave, pers. observations).

\subsection{Morphology and development}

Larval developmental stage and shell presence were determined at each time point and compared between the different treatments, according to the four morphological groups defined in section 2.3.2. Larval distribution within these groups across the different $\mathrm{pH}$ treatments is shown for the trochophore stage (Fig. 4A) and later veliger stages (Figs. 4B-D). At each developmental stage, conformity $\chi^{2}$ tests showed that the distribution within the groups was dependent on the $\mathrm{pH}(p<0.001)$.

At the first developmental stage (20 hpf trochophore), larval distribution into the different morphological groups was $\mathrm{pH}$ dependent (Fig. $4 \mathrm{~A} ; \chi^{2}=83.31$, $\mathrm{df}=6, p<$ 
310 0.001). Normal shelled larvae represented $60 \%$ of the total amount of larvae in the

311 control group, while this proportion was less than $10 \%$ at the lowest $\mathrm{pH}\left(\chi^{2}=83.31\right.$, $\mathrm{df}=$

$3126, \mathrm{p}<0.001)$. The percentage of shelled larvae, including those with normal and

313 abnormal bodies, was significantly lower at $\mathrm{pH} 7.6(47 \%)$ compared to controls (75\%)

$314 \chi^{2}=25.19$, df $\left.=2, p<0.001\right)$. In parallel, the percentage of unshelled larvae was

315 significantly greater at $\mathrm{pH} 7.6(53 \%)$ compared to controls $(10 \%) \chi^{2}=25.19, \mathrm{df}=2, p<$

316 0.001). The presence of unshelled larvae with normal bodies in the control group

317 probably occurred due to differences in the timing of shell morphogenesis among

318 individuals.

319 The distribution of veliger stages into the different morphological groups was also $320 \mathrm{pH}$ dependent, and similar to that observed in trochophore larvae (Fig. 4B-D). At 30

321 hpf, a strong decrease in the percentage of normal larvae was observed, from $60 \%$ in the control group to only $10 \%$ at the lowest $\mathrm{pH}$ (Fig. $4 \mathrm{~B} ; \chi^{2}=75.25$, df $=6, p<0.001$.

Meanwhile, the proportion of malformed or delayed larvae increased from 25 to $45 \%$.

An important impact of acidification was observed at $48 \mathrm{hpf}$, where the proportion of normal larvae decreased from $90 \%$ in the control condition to about $58 \%$ at $\mathrm{pH} 7.7$ and

326 less than $20 \%$ at $\mathrm{pH}$ 7.6. (Fig. $4 \mathrm{C} ; \chi^{2}=133.77$, $\mathrm{df}=6, p<0.001$ ). The proportion of larvae showing both shell and body abnormalities (cumulative effects) strongly increased when $\mathrm{pH}$ was reduced, from a negligible percentage in the control group, to above $65 \%$ at $\mathrm{pH} 7.6\left(\chi^{2}=133.77\right.$, df $\left.=6, \mathrm{p}<0.001\right)$. At $96 \mathrm{hpf}$, the percentage of normal larvae also drastically decreased in the reduced $\mathrm{pH}$ treatments, from $70 \%$ in the control group to $25 \%$ at $\mathrm{pH} 7.7$ and to $12 \%$ at $\mathrm{pH} 7.6$ (Fig. $4 \mathrm{D})\left(\chi^{2}=119.14\right.$, $\mathrm{df}=6, p<$ 0.001). As a result, the amount of larvae with body malformations or delayed development increased significantly with seawater acidification, from $20 \%$ in control conditions to $45 \%$ at $\mathrm{pH} 7.6$. For all three veliger stages, the proportion of larvae that showed both shell and body abnormalities (cumulative effects) strongly increased when 
336 lowering the $\mathrm{pH}$, while the proportion of larvae displaying only shell malformation

337 remained $<15 \%$ and did not differ significantly among treatments.

338 Larval shells (48 hpf) grown at lower $\mathrm{pH}$ exhibited differences in the texture and

339 porosity of the surface layer (Fig. 5). In control larvae, the mineralized protoconch

340 almost completely covered the larval body (Fig. 5A). At higher magnification, the shell

341 surface showed a uniform granular texture covered by a very thin homogeneous layer

342 (Fig. 5B). In $48 \mathrm{hpf}$ veliger larvae exposed to decreased $\mathrm{pH}$ (7.6), the protoconch

343 exhibited an irregular surface, with differences in thickness, and the homogeneous outer

344 layer was not as distinct as that of control larvae (Fig. 5C). The outer surface had a

345 porous appearance with numerous small holes interspaced between the biominerals and

346 remnants of the organic coating (Fig 5.D).

\subsection{Larval growth}

Length and width of abalone larvae reared in the three $\mathrm{pH}$ conditions were measured.

350 Only normal larvae were used in order to determine if growth rate differed according to $\mathrm{pH}$. For each treatment, a Spearman's correlation was carried out to evaluate the relationship between larval length and width during the course of the experiment (Table 2). The results showed a linear relationship between the two measures for each $\mathrm{pH}$ group (Fig. 6), allowing length and width to be combined as one parameter to estimate larval growth. The growth index (calculated as the square root of length * width) of

356 larvae exposed to the three $\mathrm{pH}$ conditions and according to time is presented in Figure $357 \quad 7$.

358 Both $\mathrm{pH}$ and time significantly affected the growth index (Table $3 \mathrm{~A} ; p=0.009$ and $p$ $359<0.001$, respectively), while the interaction term was not significant (Table $3 \mathrm{~A} ; p=$ 360 0.088). Larval size significantly increased between $20 \mathrm{hpf}$ and $30 \mathrm{hpf}$ and between 48 
361 hpf and $96 \mathrm{hpf}$ (Table 3B; Tukey, $p=0.002$ and $p=0.009$, respectively). Larval size

362 was significantly lower at $\mathrm{pH} 7.7$ and 7.6 vs 8.0 (Tukey, $p=0.008$ and $p=0.031$,

363 respectively) but did not differ significantly between the two low $\mathrm{pH}$ treatments (Table

$3643 \mathrm{~B}$; Tukey, $p=0.105)$.

365

366

\subsection{Shell calcification}

367 Under control $\mathrm{pH}$ conditions, larvae clearly exhibited the characteristic dark cross

368 indicating a radial arrangement of the aragonite crystals within 2 to 3 areas of

369 birefringence (Fig. 8B). Larvae grown at lower pH (7.6) typically showed a decrease in

370 shell birefringence indicating reduced calcification (Fig. 8D). At 30 hpf, the distribution

371 of larvae into the three categories (i.e. fully mineralized, partially mineralized and less

372 mineralized) was not significantly different between the three $\mathrm{pH}$ treatments (Fig. 9A;

373 Table $4 \mathrm{~A}, \chi^{2}=9.28$, df $\left.=4, p=0.055\right)$. At $48 \mathrm{hpf}$, the number of fully mineralized

374 larvae was strongly reduced at low $\mathrm{pH}$ conditions, while the number of partially and less

375 mineralized larvae was significantly higher (Fig. 9B; Table 4B, $p<0.001$ ). Similar

376 results were observed in 96 hpf larvae, with significant differences in larval

377 birefringence between the control group and the low pH group 7.7. (Fig. 9C; Table 4B,

$378 p<0.001)$. At $\mathrm{pH} 7.6$, larval distribution within the three categories was close to that

379 observed in the control group (Table 4B, $p=0.073$ ). 


\section{Discussion}

This study provides the first evidence that decreased $\mathrm{pH}$ negatively impacts survival, early larval development and shell calcification in the European abalone Haliotis tuberculata. Biological responses were measured over the total duration of 384 larval development (from early-hatched trochophore to the pre-metamorphic stage), using near-future oceanic $\mathrm{CO}_{2}$ levels. Our results are consistent with previous studies on mollusk larvae, in which near-future $\mathrm{CO}_{2}$ concentrations reduced survival and impaired early development, suggesting potential negative consequences for larval recruitment and the persistence of abalone populations (see reviews by Gazeau et al., 2013; Ross et al., 2011).

Our results showed that $H$. tuberculata experienced a significant decrease in larval survival at $\mathrm{pH} 7.7$ and 7.6 with a maximum decrease of $47 \%$ at $\mathrm{pH} 7.6$ relative to the control. Furthermore, low pH conditions negatively affected larval morphology, inducing a developmental delay and a decrease in the proportion of shelled larvae. In addition to

394 developmental delays and body abnormalities, seawater acidification resulted in decreased growth rate (length and width). These results are consistent with previous studies on other abalone species, such as those of Byrne et al. (2011), Crim et al. (2011) and Kimura et al. (2011) that found reduced survival in, respectively, H. coccoradiata,

398 H. kamtschatkana and H. discus hannai. Moreover, these studies showed similar results

399 with respect to increasing numbers of unshelled larvae at lower pHs (Byrne et al., 2011; 400 Crim et al., 2011), as well as reduction in larval size (Crim et al., 2011; Kimura et al., 401 2011). Abalone appears to be particularly sensitive to ocean acidification at early life 402 stages, which may lead to lower recruitment in these commercially and ecologically 403 important species. Similarly, a recent comparison of two abalone species $(H$. discus 404 hannai and $H$. diversicolor) together with the oyster Crassostrea angulata found 
reduced size to be a common response to reduced $\mathrm{pH}$ (Guo et al., 2015). Among other

406 species, deformities have been observed in the gastropod Crepidula fornicata under 407 reduced pH (Noisette et al., 2014), and the oysters Crassostrea gigas and Saccostrea 408 glomerata displayed reduced development rates and increasing levels of abnormalities 409 in low pH treatments (Kurihara et al., 2007; Kurihara, 2008; Parker et al., 2009; 410 Timmins-Schiffman et al., 2013; Watson et al., 2009). More generally, it seems that 411 reduced survival, abnormal or prolonged development and reduced size represent a 412 common response of many marine mollusk larvae exposed to elevated $\mathrm{CO}_{2}($ Gazeau et 413 al., 2013; Ross et al., 2011).

In addition to reduced survival, development abnormalities and decreased growth rate, seawater acidification also resulted in reduced shell calcification of abalone larvae, as shown by the decrease in birefringence intensity under cross-polarized light. The

417 reduction in shell calcification in larvae grown at lower $\mathrm{pH}$ treatments was highly 418 significant at later stages (48 and $96 \mathrm{hpf}$ ). However, only a slight, but not significant, increase in the percentage of partially mineralized shells was observed at $30 \mathrm{hpf}$ under low $\mathrm{pH}$ 7.7, and no significant differences were observed between control and $\mathrm{pH}$ 7.6. This could be related to low amounts of calcium carbonate in the earliest larval shell, which in combination with heterogeneous crystalline orientation, might have resulted in higher variability in the grey levels. In the future, attempts to calibrate grey scale levels 424 with measures of shell mass may allow improvements in the use of birefringence as a 425 proxy for determining shell mineralization.

Cross-polarized light and SEM observations of shelled larvae provided evidence of a lack of calcification under lower $\mathrm{pH}$, suggesting that larvae deposited less calcium carbonate and produced a thinner shell. The impacts of ocean acidification on shell calcification have been well studied in juvenile and adult mollusks, showing that their 
calcified shell is highly sensitive to elevated $\mathrm{pCO}_{2}$ (Gazeau et al., 2013). For example,

431 in the marine bivalves Mytilus edulis and C. gigas, the calcification rate was negatively 432 impacted by a short-term exposure to low $\mathrm{pH}$ (-0.2 units from ambient, Gazeau et al., 433 2007). Previous studies have reported a decrease in shell size and shell thickness as well as 434 changes in morphology and shape of the larval shell under elevated $p \mathrm{CO}_{2}$ (Gazeau et al., 435 2010; Kurihara et al., 2007, 2008; Miller et al., 2009; Talmage and Gobler, 2009). Few 436 studies have reported changes in larval shell calcification under OA stress by measuring 437 birefringence intensity; however, our results on larval abalone shell are consistent with 438 those of Kurihara et al. (2007) and Noisette et al. (2014), obtained respectively in 439 Crassostrea gigas and Crepidula fornicata, showing a reduction in larval shell 440 calcification when seawater $\mathrm{pH}$ is lowered.

Mollusk shell formation is a complex process starting at the trochophore stage in abalone. The larval shell is formed by a specialized group of ectodermal cells that form 443 the shell gland and the organic periostracum. Primary mineralization takes place between the shell gland and the periostracum, producing the so-called protoconch in gastropods (Eyster, 1986). In abalone, the first deposition of $\mathrm{CaCO}_{3}$ occurs at an early veliger stage with the deposition of amorphous calcium carbonate (ACC), which is rapidly 447 transformed into crystalline aragonite (Auzoux-Bordenave et al., 2010). Since ACC and 448 aragonite are more soluble forms of $\mathrm{CaCO}_{3}$ than calcite in lower $\mathrm{pH}$ conditions, the larval 449 shell is likely to be more susceptible to dissolution than juvenile or adult shell. In the 450 present study, SEM images of larval shells reared at pH 7.6 revealed numerous small holes at the shell surface, suggesting that $\mathrm{CaCO}_{3}$ dissolution is likely to be a factor 452 explaining reduced calcification in abalone larvae experiencing acidified conditions. 453 Shell dissolution processes may arise as a result of a lower availability of carbonate ions at 454 the site of calcification (a direct effect of the carbonate chemistry) or through indirect 
455 physiological changes in ionic composition, matrix protein formation or enzymatic 456 activities (Hüning et al., 2012).

Recent studies have suggested that lowered aragonite saturation state may be one of the key parameters controlling whether shell development in larval mollusks occurs normally

459 (Thomsen et al., 2015; Waldbusser et al., 2015). In the oyster C. gigas, developmental success and growth rates were not significantly altered as long as carbonate ion concentrations were above aragonite saturation levels, but they strongly decreased when carbonate ion concentrations dropped below aragonite saturation levels (Gazeau et al., 2011). The authors suggested that the mechanisms used by oyster larvae to regulate calcification rates were not efficient enough to compensate for the low availability of carbonate ions under acidified conditions. Interestingly, recent studies suggest that initial shell formation in larvae can occur even when aragonite is reduced below saturation levels

467 (Frieder et al., 2016), and that dissolution of the initial shell, at least in species such as $M$. edulis, only occurs at very high levels of OA (Ramesh et al., 2017). However, it is likely that resource allocation trade-offs between biomineralization and other vital biological processes will begin to occur as larval development progresses, as shown in sea urchins (Pan et al., 2015). This could help to explain why reduced birefringence of $H$. tuberculata larvae under elevated $p \mathrm{CO}_{2}$ was only observed at 48 and $96 \mathrm{hpf}$, and not at $30 \mathrm{hpf}$ (this study).

As well as directly causing shell dissolution, a number of other biological processes responsible for larval shell calcification, such as matrix protein production, chitin synthesis and enzymatic control are influenced by changes in seawater $p \mathrm{CO}_{2}$ (Weiss et al., 2013). For example, the activity of carbonic anhydrase, an enzyme that catalyzes the reversible hydration of $\mathrm{CO}_{2}$ to $\mathrm{HCO}_{3}{ }^{-}$and $\mathrm{H}^{+}$, reaches its maximum activity at the end of each developmental stage and has been correlated with larval shell biomineralization 
480 (Gaume et al., 2011; Medakovic, 2000). In the mussel M. edulis, six months of 481 incubation at $750 \mu \mathrm{atm} p \mathrm{CO}_{2}(\mathrm{pH} 7.5)$ significantly reduced carbonic anhydrase activity 482 within the mantle tissue, explaining shell growth reduction (Fitzer et al., 2014b). More 483 recently, evidence from proteomic studies suggests that elevated $p \mathrm{CO}_{2}$ influences a 484 wide range of molecular pathways, including several associated with biomineralization, 485 metabolism and the cytoskeleton, and which may correlate with calcification 486 (Dineshram et al., 2015; Harney et al., 2016).

In order to discriminate between the effect of the aragonite saturation state and the complex physiological effects of $\mathrm{pH}$ decrease on mollusk shell formation, future studies should explicitly consider $\mathrm{CaCO}_{3}$ saturation state in experimental seawater and the ability of the species to maintain internal $\mathrm{pH}$ at the site of calcification. Failure to properly biomineralise at this early stage not only results in reduced survival and developmental 492 problems for larvae (Byrne, 2012), but can also have carry-over effects later in life 493 (Hettinger et al., 2013; Rühl et al., 2017), which can explain why larval stages represent 494 such a major bottleneck for population persistence under changing environmental conditions (Przeslawski et al., 2015). In this study, fertilization was carried out under ambient conditions, and resulting embryos were transferred into experimental tanks 497 with different $p \mathrm{CO}_{2}$ conditions, as is the case of most studies assessing the impacts of 498 ocean acidification on mollusk larvae. It is now well established that exposure of adults 499 to elevated $\mathrm{CO}_{2}$ during reproductive conditioning can result in positive or negative 500 carry-over effects being transmitted from adults to their offspring, influencing the 501 resilience of mollusks to ocean acidification (Fitzer et al., 2014; Parker et al., 2013). In 502 the oyster S. glomerata, Parker et al. (2012) found that larvae from parents exposed to 503 elevated $\mathrm{CO}_{2}$ during reproductive conditioning were larger and developed faster when 504 they also experienced reduced $\mathrm{pH}$, as compared to larvae from parents conditioned 
under ambient $\mathrm{pH}$. These results highlight the importance of assessing carry-over effects

506 for determining species responses to ocean acidification. To overcome this problem,

507 future projects should conduct long-term transgenerational experiments. Biological

508 responses measured during long-term exposure to elevated $p \mathrm{CO}_{2}$, from reproducing

509 adults to larval and juvenile stages, will provide valuable information regarding

510 acclimation and adaptation of abalone to changing ocean conditions. In addition, the

511 exploration of multiple stressors known to interact with $\mathrm{pH}$ (e.g. temperature, salinity,

512 pathogens and pollutants) will result in more ecologically realistic simulations of the

513 impact of global environmental change, providing a greater understanding of ecological

514 relationships (e.g. Ko et al., 2014). Indeed, consideration of multiple stressors is also

515 crucial in fisheries and aquaculture to identify optimal conditions and adapt culturing

516 practices for sustainable shellfish production.

\section{Acknowledgements}

519 N. Wessel was supported by a post-doctoral fellowship from the MNHN (Ministère 520 de l'Enseignement Supérieur et de la Recherche, Paris, France). This work was financed in part by the ATM program "Biomineralisation" of the MNHN funded by the Ministère délégué à l'Enseignement Supérieur et à la Recherche (Paris, France). V. Julia, F. Nunes and E. Harney were supported by a grant from the Regional Council of Brittany, from

524 the European Funds (ERDF) and supported by the "Laboratoire d'Excellence" LabexMER (ANR-10-LABX-19) and co-funded by a grant from the French government under the program "Investissements d'Avenir". We thank Gérard Sinquin for his assistance in scanning electron microscopy (Plateforme d'Imagerie et de Mesures en

528 Microscopie, Université de Bretagne Occidentale, Brest). P. Dubois is a Research 529 Director of the National Fund for Scientific Research (Belgium).

530 The experiments complied with the current French laws. 


\section{Figures and tables}

532 Figure 1. Trochophore larvae grown in control condition (A) and at $\mathrm{pH} 7.6(\mathrm{~B})$. These 533 larvae were respectively classified in the morphological groups 1 (normal shelled) and 3

534 (unshelled larval phenotype). s: shell, pt: prototrochal ciliary band, at: apical tuft.

535 Dotted black arrows indicate the length and width measurements.

536

537 Figure 2. Morphological variables measured in abalone veliger larvae grown in various $538 \mathrm{pH}$ conditions; the group in brackets refers to morphological groups described in section 2.3.2. A: 30 hpf at pH 8.0 (group 1), B: 30 hpf at pH 7.6 (group 2), C: 30 hpf at pH 7.6

540 (group 4). D: 48 hpf at pH 8.0 (group 1), E: 48 hpf at pH 7.6 (group 2), F: 48 hpf at pH 7.6 (group 4). G: 96 hpf at pH 8.0 (group 1), H: 96 hpf at $\mathrm{pH} 7.6$ (group 3), I: 96 hpf at pH 7.6 (group 4). Arrows indicate attributes: eyes (e), foot (f), mantle (m), shell (s); arrowheads indicate shell abnormalities (sa) or deformed shell (ds); dotted arrows indicate the length and width measurements.

Figure 3. Viability of abalone larvae exposed to different $\mathrm{pH}$ conditions at $30 \mathrm{hpf}$ (light grey), $48 \mathrm{hpf}$ (grey) and $96 \mathrm{hpf}$ (dark grey). Errors bars represent standard deviations. Asterisks denote significant difference between control and low-pH condition (unpaired

549 Student's t-test, $p<0.05)$.

Figure 4. Morphology and development of abalone larvae exposed to different $\mathrm{pH}$ conditions at $20 \mathrm{hpf}(\mathrm{A}), 30 \mathrm{hpf}(\mathrm{B}), 48 \mathrm{hpf}(\mathrm{C})$, and $96 \mathrm{hpf}(\mathrm{D})$. Grey levels represent

553 the morphological groups, according to the developmental stage. A (trochophore

554 larvae): black: normal shelled larvae; dark grey : shelled larvae with abnormalities or delayed development; light grey: unshelled larvae with normal body; white: unshelled 
556 larvae with abnormalities or delayed development; B, C, D (veliger larvae) : black:

557 normal shelled larvae; dark grey larvae with shell malformation(s)/ normal body; light 558 grey : shelled larvae with body abnormalities or delayed development; white: larvae 559 with both shell and body abnormalities.

561 Figure 5. Scanning electron microscopy (SEM) images of abalone larvae grown under 562 control (A, B) and low $\mathrm{pH}$ condition (C, D). Shell surfaces of $48 \mathrm{hpf}$ veliger are shown. 563 A: lateral view of a $48 \mathrm{~h}$-old veliger under control $\mathrm{pH}(8.0)$; the protoconch is well 564 developed and covers almost completely the larval body; B: detail of the shell surface 565 boxed in 5A showing a uniform granular texture covered by a very thin organic coating;

566 C: lateral view of a $48 \mathrm{~h}$-old veliger exposed to low $\mathrm{pH}(7.6)$; the protoconch appears

567 well developed but exhibits an heterogeneous surface; D: detail of the protoconch 568 surface boxed in 5C showing numerous small holes interspaced between the biominerals and remnants of the organic coating.

Figure 6. Correlation between length and width for each $\mathrm{pH}$ treatment. Light grey represents the control $\mathrm{pH}(8.0)$, dark grey represents the $\mathrm{pH} 7.7$, and black represents the pH 7.6. Results of the statistical analyses are reported in Table 2.

Figure 7. Effect of decreased $\mathrm{pH}$ on abalone larval growth, expressed as square roots of (length $\mathrm{x}$ width) at $20 \mathrm{hpf}(\mathrm{A}), 30 \mathrm{hpf}(\mathrm{B}), 48 \mathrm{hpf}$ (C), and $96 \mathrm{hpf}(\mathrm{D})$. Grey level of

577 the boxes denote the different $\mathrm{pH}$ conditions. Centre lines of box plots show the 578 medians; box limits indicate the first and third quartile respectively with lines encompassing data within 1.5 times the spread from the median $(p<0.05)$. Results of the statistical analyses are reported in Table 3. 
582 Figure 8. Morphology and shell birefringence of 48 hpf veliger larvae grown under

583 control (A, B) and low $\mathrm{pH}$ conditions (C, D). Larvae were observed under phase 584 contrast $(\mathrm{A}, \mathrm{C})$ and polarized microscopy (B, D). Normal larvae under control pH (8.0) 585 showing the characteristic black cross of birefringence (A, B). Shell abnormalities in 586 larvae exposed to low $\mathrm{pH}(7.7)$ result in a significant decrease of calcified areas (C, D).

588 Figure 9. Shell mineralization of larval abalone determined by polarized light 589 microscopy for each development stage (A: 30hpf, B: 48hpf, C: 96hpf). Grey levels represent the three categories of mineralization: black bars for fully mineralized (birefringence $>90 \%)$; stripe bars for partially mineralized $(70 \%<$ birefringence $<$ $59290 \%$ ) and dotted bars for less mineralized shells (birefringence $<70 \%$ ). Differences in

593 larval distribution across $\mathrm{pH}$ treatments were tested using a homogeneity $\chi^{2}$ test by 594 treating birefringence as a categorical factor $(\mathrm{n}=40$ larvae per $\mathrm{pH}$ condition). Results of the statistical analyses are reported in Table 4.

Table 1. Mean parameters of seawater carbonate chemistry during the experiment.

598 Seawater $\mathrm{pH}$ on the total scale $\left(\mathrm{pH}_{T}\right)$, temperature $\left(17.0 \pm 0.5^{\circ} \mathrm{C}\right)$, salinity $(37.0 \pm 0.1)$ and total alkalinity (mean $2344 \mu$ Eq.kg- ${ }^{1}$ ) were used to calculate $\mathrm{CO}_{2}$ partial pressure $600\left(\mathrm{CO}_{2} ; \mu \mathrm{atm}\right)$, Dissolved Inorganic Carbon (DIC; $\mu$ mol.kg SW), $\mathrm{HCO}_{3}^{-}, \mathrm{CO}_{3}{ }^{2-}$, 601 aragonite saturation state $(\Omega$ ar) and calcite saturation state $(\Omega$ calc) by using the $602 \mathrm{CO}_{2} \mathrm{SYS}$ software. $\mathrm{pH}_{\mathrm{T}}$ is the average value logged throughout the 5 days of experiment 603 (every $15 \mathrm{mn}$ ) in the two tanks $(\mathrm{n}=96 /$ tank). Temperature and salinity were measured daily $(n=5)$; total alkalinity was measured twice $(n=2)$. Results are expressed as mean $\pm \mathrm{SD}$. 
608 Table 2: Results of the Spearman's correlation performed to evaluate the nullity of 609 correlation between larval length and width for each $\mathrm{pH}$ treatment in the course of the 610 experiment.

611

612 Table 3. Summary of statistics used to test the differences in larval growth.

613 A. Results of the repeated measures ANOVA on larval growth index (square root of 614 length * width); B. Multiple comparison Tukey tests testing the effects of $\mathrm{pH}$ (fixed 615 crossed factor) according to time (fixed repeated factor). Significant results in bold ( $p<$ $6160.05)$

618 Table 4. Summary of statistics used to test the differences in shell birefringence.

619 A. Homogeneity $\chi^{2}$ test used to test the effect of $\mathrm{pH}$ on shell birefringence, for each 620 development stage. B. Pair-wise Wilcoxon rank sum test showing differences between $621 \mathrm{pH}$ groups; Bonferronni adjusted $p$-values. Significant results in bold $(p<0,05)$.

623 Supplementary Figure S1. A. Cross-polarized microscopy image of abalone larvae (48 $624 \mathrm{hpf}$ ) showing the three regions of interest (ROI) selected for the analysis of 625 birefringence intensity. B. Quantification of grey-scale levels (in pixels) in the three 626 ROI. The values were averaged to provide a global mean grey level for each larval shell $627(\mathrm{n}=40$ larvae per $\mathrm{pH}$ condition $)$.

628 


\section{References}

631 Auzoux-Bordenave, S., Badou, A., Gaume, B., Berland, S., Helléouet, M.-N., Milet, C., and Huchette, S. 2010. Ultrastructure, chemistry and mineralogy of the growing shell of the European abalone Haliotis tuberculata. J. Struct. Biol. 171: 277-290.

Byrne, M. 2012. Global change ecotoxicology: Identification of early life history bottlenecks in marine invertebrates, variable species responses and variable experimental approaches. Mar. Environ. Res. 76: 3-15.

Byrne, M., Ho, M., Wong, E., Soars, N. A., Selvakumaraswamy, P., Shepard-Brennand, H., Dworjanyn, S. A., et al. 2011. Unshelled abalone and corrupted urchins: development of marine calcifiers in a changing ocean. Proc. R. Soc. B: Biological Sciences, 278: 2376-2383.

Comeau, S., Gorsky, G., Alliouane, S., and Gattuso, J.- P. 2010. Larvae of the pteropod Cavolinia inflexa exposed to aragonite undersaturation are viable but shell-less. Mar. Biol. 157: 2341-2345.

644 Cook, P. A. 2014. The Worldwide Abalone Industry. Modern Economy, 05: 1181-1186.

645 Courtois de Viçose, G., Viera, M. P., Bilbao, A., and Izquierdo, M. S. 2007. Embryonic and larval development of Haliotis tuberculata coccinea Reeve: an indexed microphotographic sequence. J. Shellfish Res. 26: 847-854.

Crim, R. N., Sunday, J. M., and Harley, C. D. G. 2011. Elevated seawater $\mathrm{CO}_{2}$ concentrations impair larval development and reduce larval survival in endangered northern abalone (Haliotis kamtschatkana). J. Exp. Mar. Biol. Ecol. 400: 272-277.

Dickson, A.G., Sabine, C.L., Christian, J.R. (Eds), 2007. Guide to best practices for ocean $\mathrm{CO}_{2}$ measurements. PICES Special Publication, 3: $191 \mathrm{pp}$.

Dickson, A.G. 2010. The carbon dioxide system in seawater: equilibrium chemistry and 654 measurements. In Guide to Best Practices for Ocean Acidification Research and 
Data Reporting pp.17-40. Ed. By U. Riebesell, V. J. Fabry, L. Hansson and J.-P. Gattuso). Luxembourg: Publications Office of the European Union.

Dickson, A.G., and Millero, F.J. 1987. A comparison of the equilibrium constants for the dissociation of carbonic acid in seawater media. Deep Sea Res. 34: 1733-1743.

Dineshram, R., Quan, Q., Sharma, R., Chandramouli, K., Yalamanchili, H.K., Chu, I. and Thiyagarajan, V., 2015. Comparative and quantitative proteomics reveal the adaptive strategies of oyster larvae to ocean acidification. Proteomics 15, 41204134.

Doncaster, C. P. and Davey, A. J. H. 2007. Analysis of Variance and Covariance: How 664 to Choose and Construct Models for the Life Sciences. Cambridge: Cambridge University Press.

Ekstrom, J., Suatoni, L., Cooley, S., Pendleton, L., Waldbusser, G., Cinner, J., Ritter, J., 667 Langdon, C., van Hooidonk, R., Gledhill, D., Wellman, K., Beck, M., Brander, L., 668 Rittschof, D., Doherty, C., Edwards, P. \& Portela, R. 2015. Vulnerability and adaptation of US shellfisheries to ocean acidification. Nature Climate Change, 5: 207-214.

Ellis, R. P., Bersey, J., Rundle, S. D., Hall-Spencer, J. M., and Spicer, J. I. 2009. Subtle but significant effects of $\mathrm{CO}_{2}$ acidified seawater on embryos of the intertidal snail, Littorina obtusata. Aquat. Biol. 5: 41-48.

Eyster, LS. 1986. Shell inorganic composition and onset of shell mineralization during bivalve and gastropod embryogenesis. Biol. Bull. 170:211-231

677

Fitzer, S.C., Cusack, M., Phoenix, V.R., Kamenos, N.A. 2014. Ocean acidification 678 reduces the crystallographic control in juvenile mussel shells. J. Struct. Biol. 188 : 678 39-45. 
679 Fitzer, S.C., Phoenix, V.R., Cusack, M., Kamenos, N.A. 2014b. Ocean acidification 680 impacts mussel control on biomineralisation. Sci. Rep. 4, 6218. (doi:10.1038/srep06218).

682

683 Frieder, C.A., Applebaum, S.L., Pan, T.-C.F., Hedgecock, D. and Manahan, D.T., 2016.

684 Metabolic cost of calcification in bivalve larvae under experimental ocean 685 acidification. ICES J. Mar. Sci. 74: 941-954.

686

Gattuso, J. P., Magnan, A., Bille, R., Cheung, W. W. L., Howes, E. L., Joos, F., 687 Allemand, D., et al. 2015. Contrasting futures for ocean and society from different anthropogenic $\mathrm{CO}_{2}$ emissions scenarios. Science 349: aac4722.

Gaume, B., Fouchereau-Peron, M., Badou, A., Helléouet, M.-N., Huchette, S., and Auzoux-Bordenave, S. 2011. Biomineralization markers during early shell formation in the European abalone Haliotis tuberculata, Linnaeus. Mar. Biol. 158: 341-353.

Gazeau, F., Gattuso, J. P., Dawber, C., Pronker, A. E., Peene, F., Peene, J., Heip, C. H. R., et al. 2010. Effect of ocean acidification on the early life stages of the blue mussel Mytilus edulis. Biogeosciences 7: 2051-2060.

Gazeau, F., Parker, L. M., Comeau, S., Gattuso, J.-P., O’Connor, W. A., Martin, S., 697 Pörtner, H.-O., et al. 2013. Impacts of ocean acidification on marine shelled mollusks. Mar. Biol. 160: 2207-2245.

699 Gazeau, F., Quiblier, C., Jansen, J. M., Gattuso, J.-P., Middelburg, J. J., and Heip, C. H. R. 2007. Impact of elevated $\mathrm{CO}_{2}$ on shellfish calcification. Geophys. Res. Lett. 34.

Guo, X., Huang, M., Pu, F., You, W., and Ke, C. 2015. Effects of ocean acidification 702 caused by rising $\mathrm{CO}_{2}$ on the early development of three mollusks. Aquat. Biol. 23: 147-157. 
Harney, E., Artigaud, S., Le Souchu, P., Miner, P., Corporeau, C., Essid, H., Pichereau, V., et al. 2016. Non-additive effects of ocean acidification in combination with warming on the larval proteome of the Pacific oyster, Crassostrea gigas. J Proteomics 135: 151-161.

Hendriks, I. E., Duarte, C. M., and Álvarez, M. 2010. Vulnerability of marine biodiversity to ocean acidification: A meta-analysis. Estuar. Coast. Shelf. Sci. 86: 157-164.

Hettinger, A., Sanford, E., Hill, T. M., Lenz, E. A., Russell, A. D., and Gaylord, B. 2013. Larval carry-over effects from ocean acidification persist in the natural environment. Glob. Change Biol. 19, 3317-3326, doi: 10.1111/gcb.12307

Hofmann, G.E., Barry, J.P., Edmunds, P.J., Gates, R.D., Hutchins D.A., Klinger, T., and Sewell, M.A. 2010. The effect of ocean acidification on calcifying organisms in marine ecosystems: An organism-to-ecosystem perspective. Annu. Rev. Ecol. Evol. Syst. 41: 127-147.

Huchette, S., and Clavier, J. 2004. Status of the ormer (Haliotis tuberculata L.) industry in Europe. J. Shellfish Res. 23 : 951-955.

Hüning, A. K., Melzner, F., Thomsen, J., Gutowska, M. A. , Krämer, L. , Frickenhaus, S. , Rosenstiel, P. , Pörtner, H. O. , Philipp, E. E. R. and Lucassen, M. 2012. Impacts of seawater acidification on mantle gene expression patterns of the Baltic Sea blue mussel: implications for shell formation and energy supply. Marine Biology. doi: 10.1007/s00227-012-1930-9

IPCC, 2014. Summary for Policymakers. In: Climate Change 2014: Impacts, Adaptation, and Vulnerability. Part A: Global and Sectoral Aspects. Contribution of Working Group II to the Fifth Assessment Report of the Intergovernmental Panel on Climate Change. Cambridge University Press, Cambridge, United Kingdom and New York, NY, USA, pp. 1-32. 
Jardillier E., Rousseau M., Gendron-Badou A., Fröhlich F., Smith D.C., Martin M., Helléouet M.-N., Huchette S., Doumenc D., Auzoux-Bordenave S., 2008. A morphological and structural study of the larval shell from the abalone Haliotis tuberculata. Mar. Biol. 154 (4): 735-744.

Kimura, R. Y. O., Takami, H., Ono, T., Onitsuka, T., and Nojiri, Y. 2011. Effects of elevated $\mathrm{pCO}_{2}$ on the early development of the commercially important gastropod, Ezo abalone Haliotis discus hannai. Fish. Oceanogr. 20: 357-366.

Ko, G., Dineshram, R., Campanati, C., Vera, S., Havenhand, J. \& Thiyagarajan, V. 2014. Interactive effects of ocean acidification, elevated temperature and reduced salinity on early-life stages of the Pacific oyster. Environmental Science \& Technology, 48: 10079-10088.

Kroeker, K. J., Kordas, R. L., Crim, R. N., and Singh, G. G. 2010. Meta-analysis reveals negative yet variable effects of ocean acidification on marine organisms. Ecol. Lett. 13: $1419-1434$.

Kurihara, H. 2008. Effects of $\mathrm{CO}_{2}$-driven ocean acidification on the early developmental stages of invertebrates. Mar. Ecol. Prog. Ser. 373: 275-284.

Kurihara, H., Asai, T., Kato, S., and Ishimatsu, A. 2008. Effects of elevated $p \mathrm{CO}_{2}$ on early development in the mussel Mytilus galloprovincialis. Aquat. Biol. 4: 225-233.

Kurihara, H., Kato, S., and Ishimatsu, A. 2007. Effects of increased seawater $p \mathrm{CO}_{2}$ on early development of the oyster Crassostrea gigas. Aquat. Biol. 1: 91-98.

Lewis, E., and Wallace, D.W.R. 1998. Program developed for $\mathrm{CO}_{2}$ system calculations. Carbon Dioxide Information Analysis Center, Oak Ridge National Laboratory, U.S. Department of Energy

Martin, S., Richier, S., Pedrotti, M. L., Dupont, S., Castejon, C., Gerakis, Y., Kerros, M. E., et al. 2011. Early development and molecular plasticity in the Mediterranean sea 
urchin Paracentrotus lividus exposed to $\mathrm{CO}_{2}$-driven acidification. J. Exp. Biol. 214: $1357-1368$.

757

758

759

760

761

762

763

764

765

766

767

768

769

770

771

772

773

774

775

Medakovic, D., 2000. Carbonic anhydrase activity and biomineralization process in embryos, larvae and adult blue mussels Mytilus edulis L. Helgol Mar Res 54:1-6. doi:10.1007/s101520050030

Mehrbach, C., Culberso, C., Hawley, J.E., and Pytkowic, R.M. 1973. Measurement of apparent dissociation-constants of carbonic-acid in seawater at atmospheric pressure. Limnol. Oceanogr. 18: 897-907.

Miller, A.W., Reynolds, A.C., Sobrino, C., and Riedel, G.F. 2009. Shellfish Face Uncertain Future in High $\mathrm{CO}_{2}$ World: Influence of Acidification on Oyster Larvae Calcification and Growth in Estuaries. PLoS ONE 4(5): e5661. doi:10.1371/journal.pone.0005661

Morash, A. J., and Alter K., 2015. Effects of environmental and farm stress on abalone physiology: perspectives for abalone aquaculture in the face of global climate change. Reviews in Aquaculture, (2015) 7, 1-27.

Noisette, F., Comtet, T., Legrand, E., Bordeyne, F., Davoult, D., and Martin, S. 2014. Does Encapsulation Protect Embryos from the Effects of Ocean Acidification? The example of Crepidula fornicata. PLoS ONE, 9: e93021.

Orr, J. C., Fabry, V. J., Aumont, O., Bopp, L., Doney, S. C., Feely, R. A., Gnanadesikan, A., et al. 2005. Anthropogenic ocean acidification over the twentyfirst century and its impact on calcifying organisms. Nature, 437: 681-686.

Pan, T.-C.F., Applebaum, S.L. and Manahan, D.T., 2015. Experimental ocean acidification alters the allocation of metabolic energy. Proc. Natl. Acad. Sci. 112: $4696-4701$. 
Parker, L., Ross, P., O’Connor, W., Borysko, L., Raftos, D. \& Pörtner, H. 2012. Adult exposure influences offspring response to ocean acidification in oysters. Glob. Change Biol.18: 82-92.

Parker, L., Ross, P., O'Connor, W., Pörtner, H., Scanes, E., and Wright, J. 2013. Predicting the Response of Mollusks to the Impact of Ocean Acidification. Biology,

Parker, L. M., Ross, P. M., and O'Connor, W. A. 2009. The effect of ocean acidification and temperature on the fertilization and embryonic development of the Sydney rock oyster Saccostrea glomerata (Gould 1850). Glob. Change Biol. 15: 2123-2136.

Parker, L. M., Ross, P. M., and O’Connor, W. A. 2010. Comparing the effect of elevated $\mathrm{pCO}_{2}$ and temperature on the fertilization and early development of two species of oysters. Mar. Biol. 157: 2435-2452.

Przeslawski, R., Byrne, M., and Mellin, C. 2015. A review and meta-analysis of the effects of multiple abiotic stressors on marine embryos and larvae. Glob. Change Biol. 21: 2122-2140.

R Development Core Team. 2014. R: A language and environment for statistical computing. R Foundation for Statistical Computing, Vienna, Austria.

Ramesh, K., Hu, M.Y., Thomsen, J., Bleich, M. and Melzner, F., 2017. Mussel larvae modify calcifying fluid carbonate chemistry to promote calcification. Nat. Commun. 8: 1-8.

Riebesell, U., Fabry, V. J., Hansson, L., and Gattuso, J.-P. 2010. Guide to Best Practices for Ocean Acidification Research and Data Reporting (Publications Office of the European Union).

Ross, P. M., Parker, L., O’Connor, W. A., and Bailey, E. A. 2011. The Impact of Ocean Organisms. Water, 3: 1005-1030. 
Rühl, S., Calosi, P., Faulwetter, S., Keklikoglou, K., Widdicombe, S. and Queirós, A.M., 2017. Long-term exposure to elevated pCO 2 more than warming modifies early-life shell growth in a temperate gastropod. ICES J. Mar. Sci. 74: 1113-1124.

Talmage, S.C., and Gobler, C.J., 2009. The effects of elevated carbon dioxide concentrations on the metamorphosis, size, and survival of larval hard clams (Mercenaria mercenaria), bay scallops (Argopecten irradians), and Eastern oysters (Crassostrea virginica). Limnol. Oceanogr. 54:2072-2080

Talmage, S. C., and Gobler, C.J. 2010. Effects of past, present and future ocean carbon dioxide concentrations on the growth and survival of larval shellfish. Proc. Natl.

Thomsen, J., Haynert, K.,, Wegner, K. M., and Melzner, F., 2015. Impact of seawater Acad. Sci. USA 107: 17246-172.

Timmins-Schiffman, E., O’Donnell, M. J., Friedman, C.S., and Roberts, S. B. 2013. Elevated $\mathrm{pCO}_{2}$ causes developmental delay in early larval Pacific oysters, Crassostrea gigas. Mar. Biol. 160: 1973-1982.

Travers, M.-A., Basuyaux, O., Le Goïc, N., Huchette, S., Nicolas, J.-L., Koken, M., and Paillard, C. 2009. Influence of temperature and spawning effort on Haliotis tuberculata mortalities caused by Vibrio harveyi: an example of emerging vibriosis linked to global warming. Glob. Change Biol. 15: 1365-1376.

Waldbusser, G.G., Hales, B., Langdon, C. J., Haley, B. A., Schrader, P., Brunner, E. L., Gray, W. P., et al. 2015. Saturation-state sensitivity of marine bivalve larvae to ocean acidification. Nat. Clim. Change 5:273-280. 
828 Watson, S.-A., Southgate, P. C., Tyler, P. A., and Peck, L. S. 2009. Early Larval

829 Development of the Sydney Rock Oyster Saccostrea glomerata Under Near-Future 830 Predictions of $\mathrm{CO}_{2}$-Driven Ocean Acidification. J. Shellfish Res. 28: 431-437.

831 Weiss, I.M., Lüke, F., Eichner, N., Guth, C and Clausen-Schaumann, H., 2013. On the 832 function of chitin synthase extracellular domains in biomineralization. J. Struct. 833 Biol. 183 (2): 216-225.

834 Widdicombe, S., and Spicer, J. I. 2008. Predicting the impact of ocean acidification on 835 benthic biodiversity: What can animal physiology tell us? J. Exp. Mar. Biol. Ecol. $836 \quad 366: 187-197$.

837 Wittmann, A.C., and Pörtner, H-O. 2013. Sensitivities of extant animal taxa to ocean 838 Acidification. Nat. Clim. Change 3: 995-1001.

839 Zippay, M.L., and Hofmann, G.E. 2010. Effect of $\mathrm{pH}$ on gene expression and thermal 840 tolerance of early life history stages of red abalone Haliotis rufescens. J. Shellfish 841 Res. 29: 429-439. 
Supplementary Figure S1:

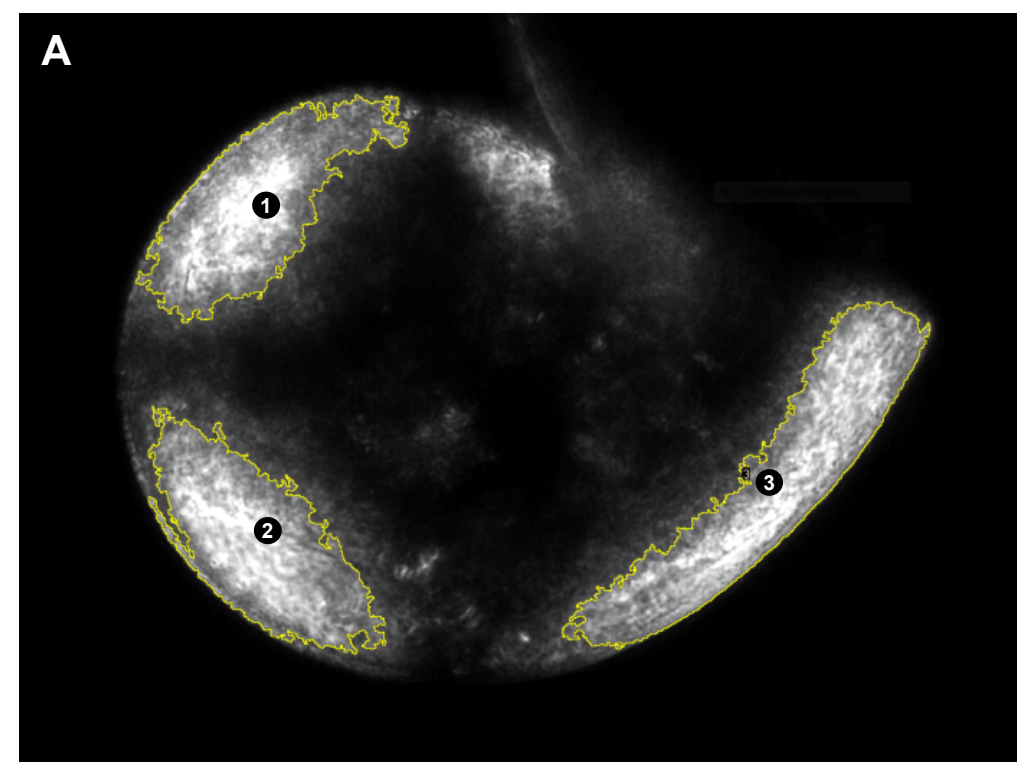

B

\begin{tabular}{|c|c|}
\hline ROI & Grey-scale level \\
\hline 1 & 97,977 \\
\hline 2 & 98,022 \\
\hline 3 & 100,713 \\
\hline Mean & 98,90 \\
\hline SD & 1,28 \\
\hline
\end{tabular}


Figure 1
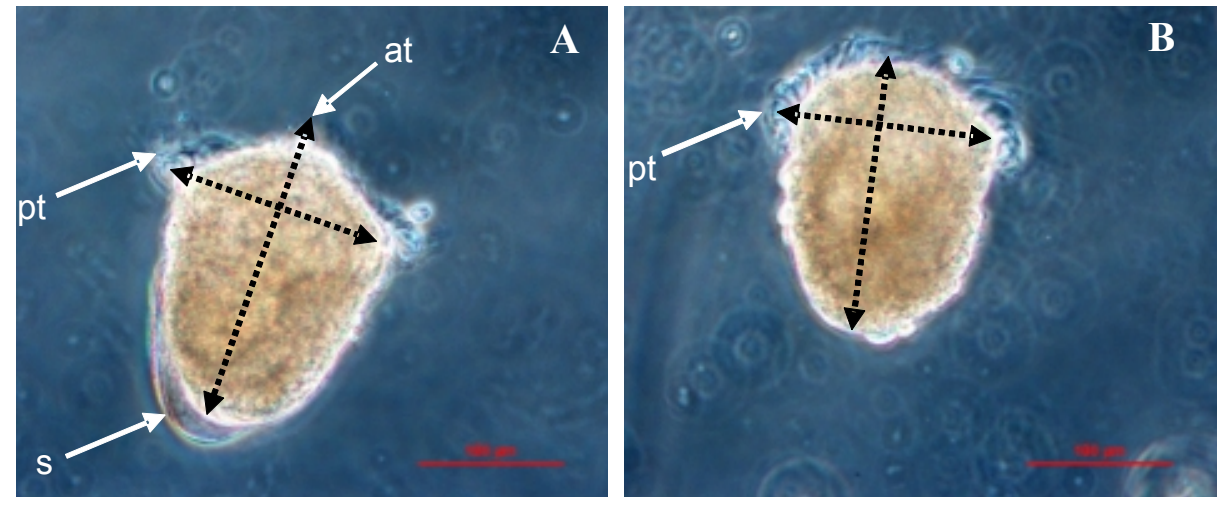
Figure 2
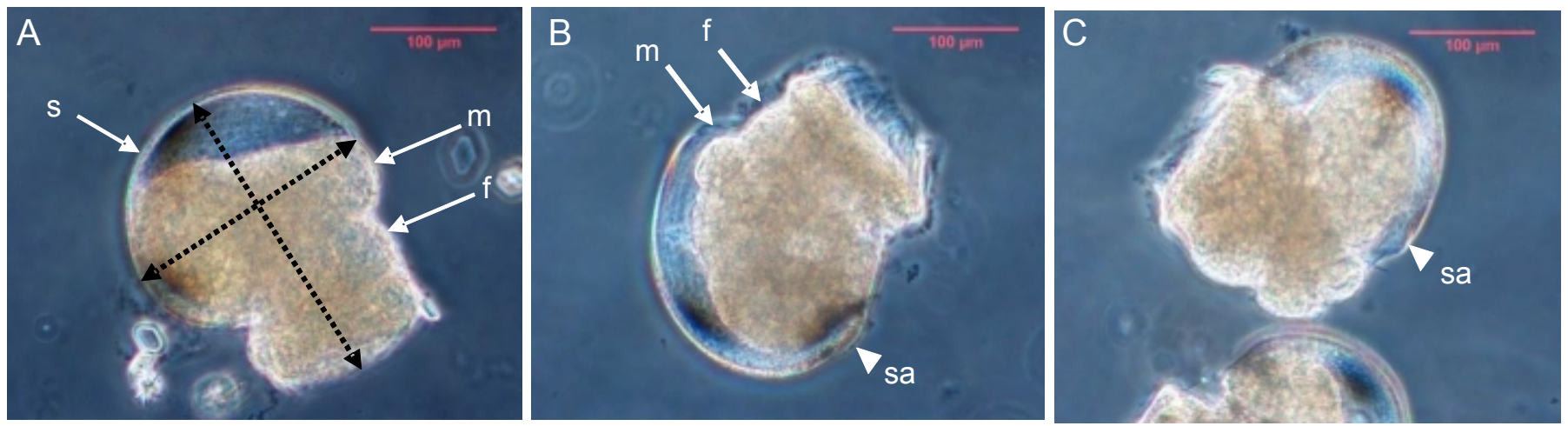

D
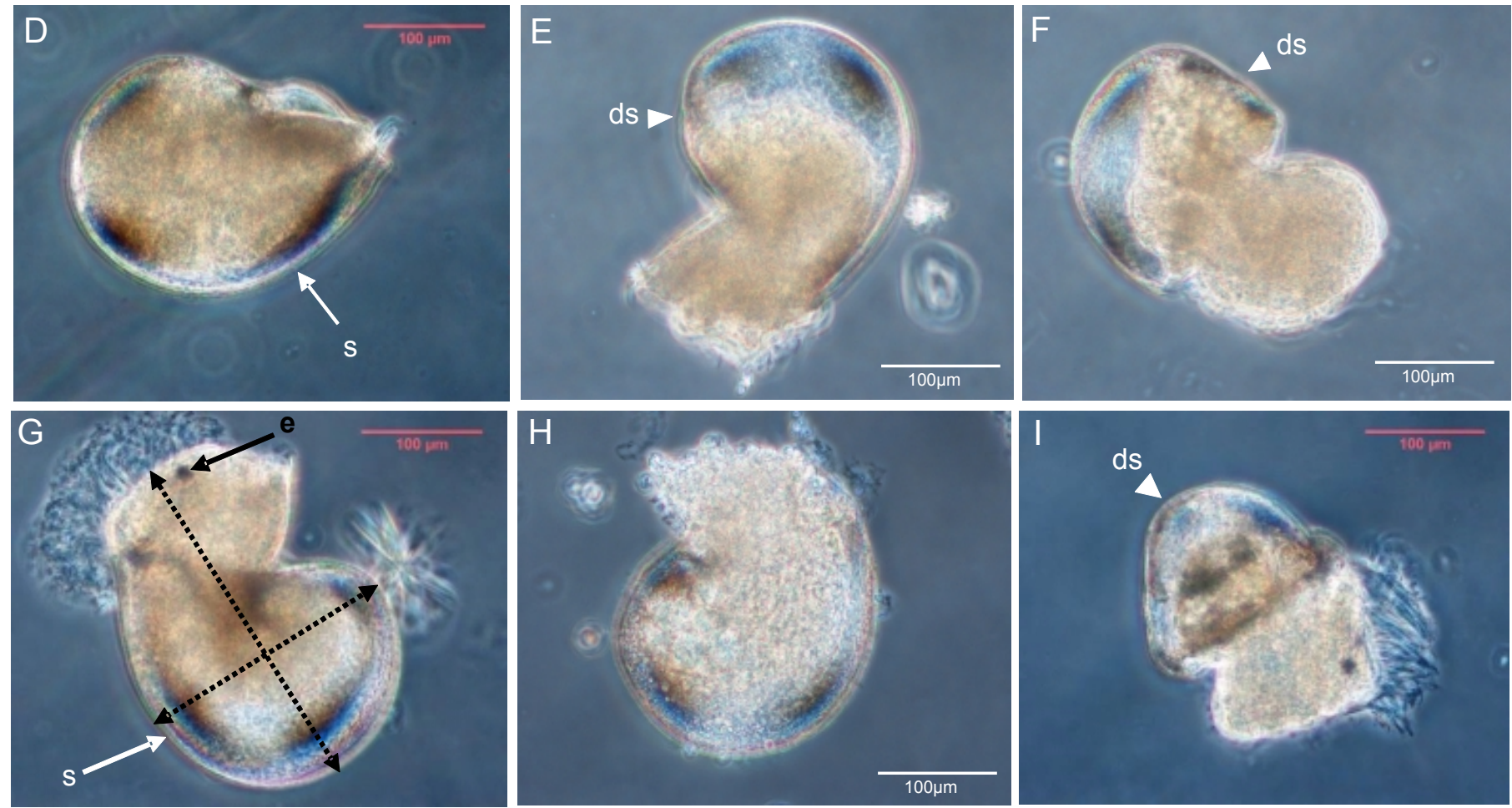
Figure 3

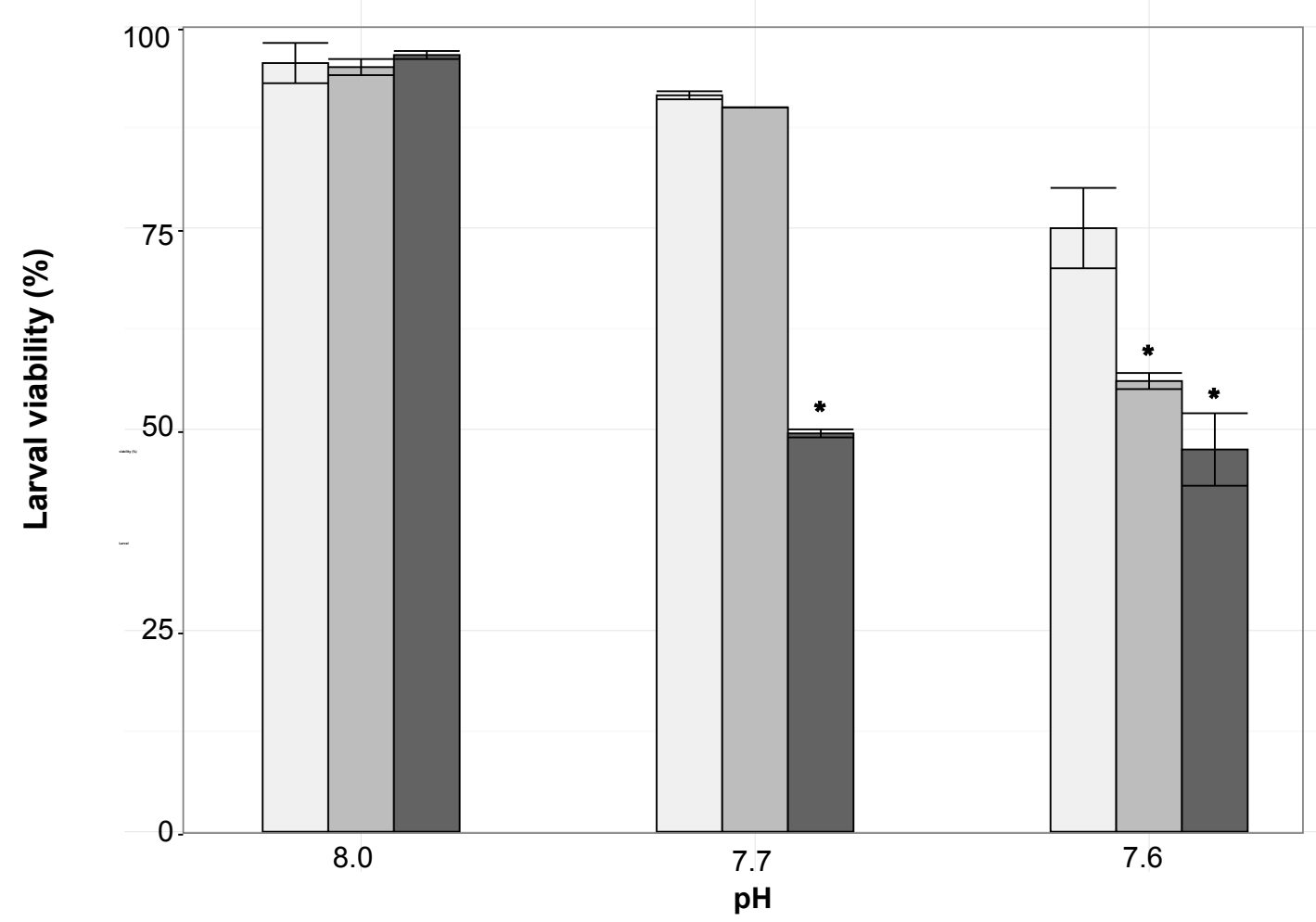


Figure 4
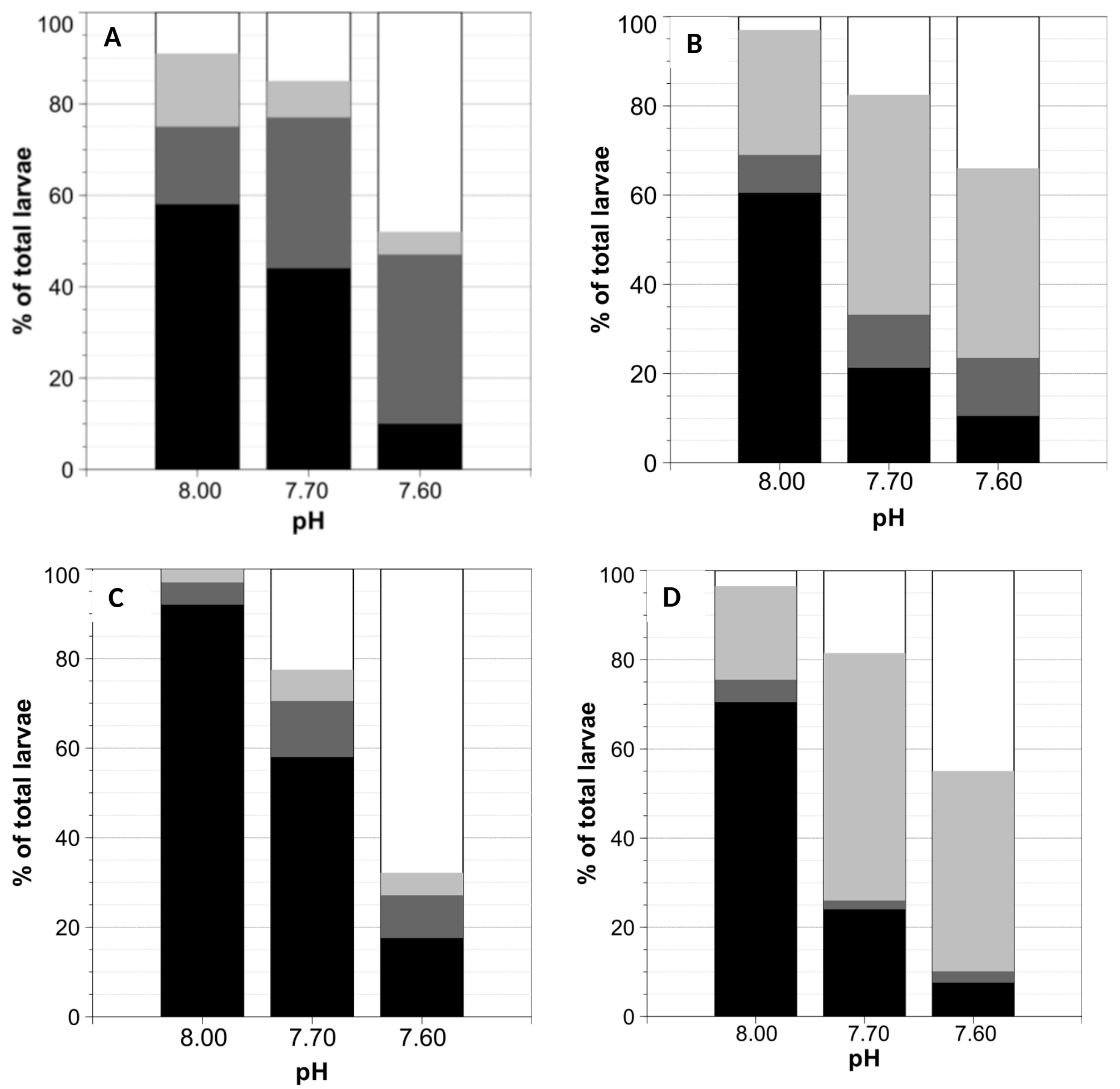
Figure 5
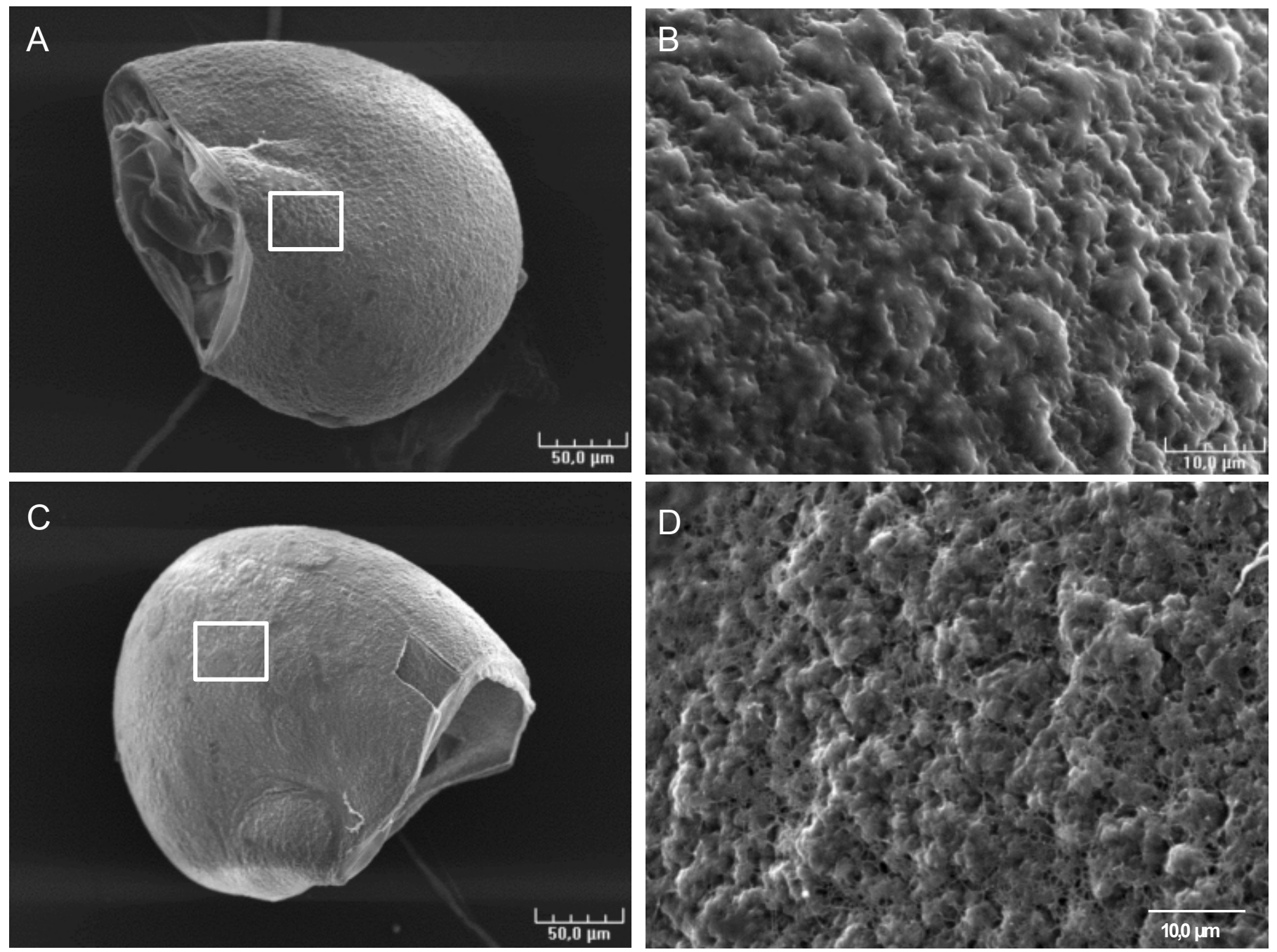
Figure 6

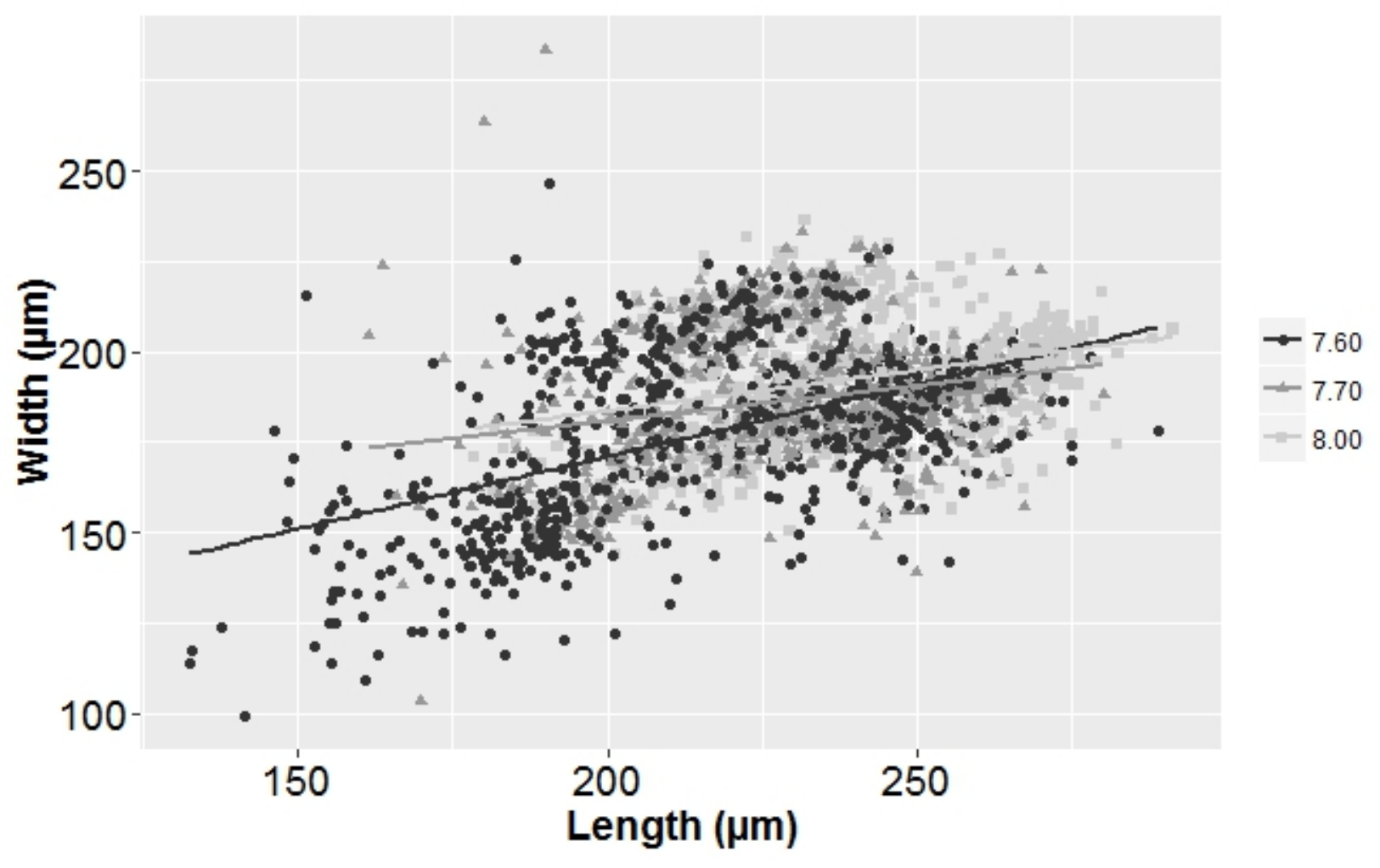


Figure 7
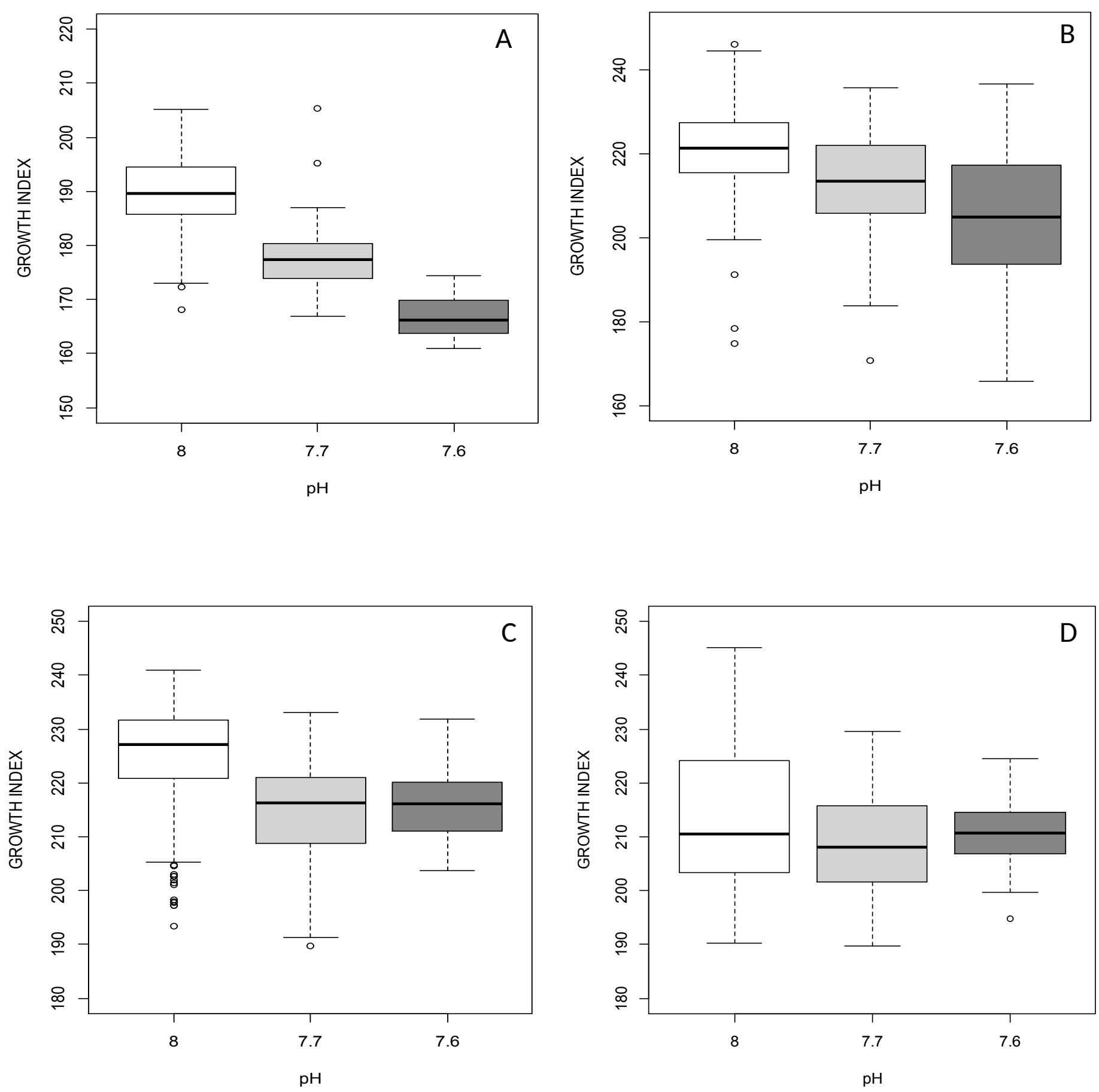
Figure 8
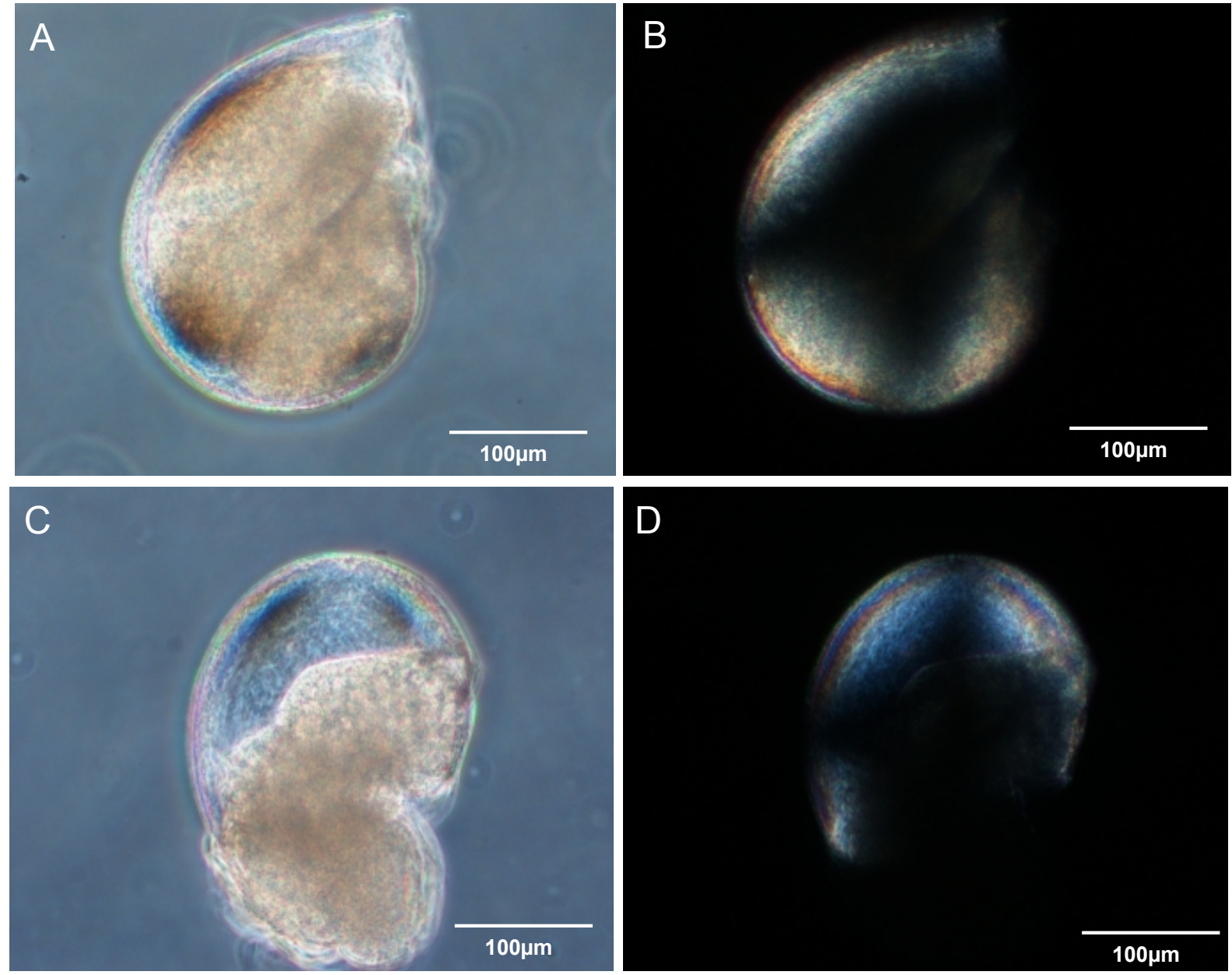
Figure 9
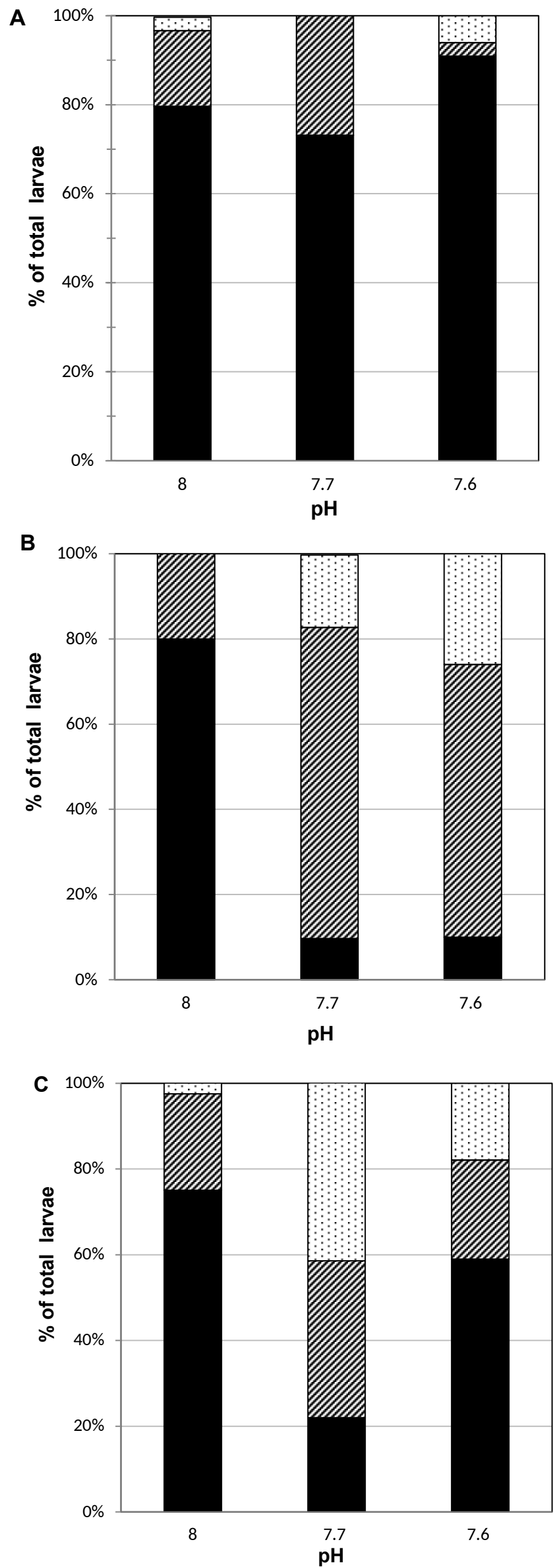

๑Less mineralized $\mathbb{Z}$ Partially mineralized $\quad$ Fully mineralized 
Table 1.

\begin{tabular}{|c|c|c|c|c|c|c|c|}
\hline Nominal $\mathrm{pH}$ & $\mathrm{pHT}$ & $\mathrm{pCO}_{2}(\mu \mathrm{atm})$ & $\mathrm{DIC}\left(\mu \mathrm{mol} / \mathrm{kg}^{-1}\right)$ & $\mathrm{HCO}_{3}{ }^{-}\left(\mu \mathrm{mol} / \mathrm{kg}^{-1}\right)$ & $\mathrm{CO}_{3}{ }^{2-}\left(\mu \mathrm{mol} / \mathrm{kg}^{-1}\right)$ & $\Omega$ ar & $\Omega$ calc \\
\hline 8.1 & $8.00 \pm 0.002$ & $460 \pm 3$ & $2119 \pm 2$ & $1940 \pm 3$ & $163 \pm 1$ & $2,47 \pm 0,01$ & $3,8 \pm 0,02$ \\
\hline 7.7 & $7.68 \pm 0,001$ & $1055 \pm 3$ & $2254 \pm 1$ & $2132 \pm 0,05$ & $85,4 \pm 0,3$ & $1,30 \pm 0,01$ & $2 \pm 0,01$ \\
\hline 7.6 & $7.58 \pm 0,003$ & $1331 \pm 10$ & $2286 \pm 2$ & $2170 \pm 2$ & $70,1 \pm 0,6$ & $1,06 \pm 0,01$ & $1,6 \pm 0,01$ \\
\hline
\end{tabular}


Table 2.

\begin{tabular}{|lll|}
\hline Treatment $(\mathrm{pH})$ & Rho & p-value \\
\hline 8.0 & 0.2842896 & $<0.001$ \\
\hline 7.7 & 0.1919181 & $<0.001$ \\
\hline 7.6 & 0.4593034 & $<0.001$ \\
\hline
\end{tabular}


Table 3.

\section{A. Repeated measures ANOVA}

\begin{tabular}{ccccc}
\hline $\begin{array}{c}\text { Effect } \\
\text { between subjects }\end{array}$ & df & MS & F-ratio & $p$-value \\
\hline pH & 2 & 357.3 & 33.1 & $\mathbf{0 . 0 0 9}$ \\
\hline Error & 3 & 10.8 & & \\
\hline $\begin{array}{c}\text { Effect } \\
\text { within subjects }\end{array}$ & df & MS & F-ratio & $p$-value \\
\hline Time & 3 & 1998 & 141.6 & $<\mathbf{0 . 0 0 1}$ \\
\hline Time $*$ pH & 6 & 38.0 & 2.7 & 0.088 \\
\hline Error & 9 & 14.1 & & \\
\hline
\end{tabular}

\section{B. Multiple comparisons}

on factor time: $\quad p$-value

$\begin{array}{ll}\text { 20h vs 30h } & \mathbf{0 . 0 0 2} \\ \text { 20h vs 48h } & <\mathbf{0 . 0 0 1} \\ \text { 20h vs 96h } & <\mathbf{0 . 0 0 1} \\ \text { 30h vs 48h } & 0.159 \\ \text { 30h vs 96h } & 0.418 \\ \text { 48h vs 96h } & \mathbf{0 . 0 0 9}\end{array}$

on factor $\mathrm{pH}$ : $\quad p$-value
7.6 vs 7.7
0.105
7.6 vs 8.0
0.008
7.7 vs 8.0
0.031 
Table 4.

A. Homogeneity $\chi^{2}$ test

\begin{tabular}{cccc}
\hline Development Time & Chi-sq & df & $\boldsymbol{p}$-value \\
\hline $30 \mathrm{~h}$ & 9.28 & 4 & 0.055 \\
\hline $48 \mathrm{~h}$ & 67.53 & 4 & $<\mathbf{0 . 0 0 1}$ \\
\hline $96 \mathrm{~h}$ & 28.48 & 4 & $<\mathbf{0 . 0 0 1}$ \\
\hline
\end{tabular}

B. Pair wise Wilcoxon rank sum test

\begin{tabular}{ccc} 
& $48 \mathrm{~h}$ & $96 \mathrm{~h}$ \\
\hline $\mathbf{p H}$ factor & $\boldsymbol{p}$-value & $\boldsymbol{p}$-value \\
\hline 7.7 vs 8.0 & $<\mathbf{0 . 0 0 1}$ & $<\mathbf{0 . 0 0 1}$ \\
\hline 7.6 vs 8.0 & $<\mathbf{0 . 0 0 1}$ & 0.073 \\
\hline 7.6 vs 7.7 & 0.49 & $\mathbf{0 . 0 0 1 6}$ \\
\hline
\end{tabular}

